\title{
Magical Serialism: Modernist Enchantment in Elisabeth Lutyens's 0 Saisons, 0 Châteaux!
}

\section{ANNIKA FORKERT}

\begin{abstract}
Elisabeth Lutyens's music of the 1940s and 1950s provides one important, but frequently overlooked, link between British music and modernism before the so-called Manchester School. I argue that the main reason that the composer and her music have not yet received much attention is that early twentieth-century modernism, as it is commonly understood, has been gendered masculine. This article engages with the composition, texts, and reception of Lutyens's 1946 cantata 0 saisons, ô châteaux! in the context of other Lutyens pieces in order to argue that the composer sought to transcend what she perceived as a complex of disadvantages in the reception of her music (both regarding her gender and composition technique): the Cantata is an essentially melodic piece of 'magical serialism'. Rather than 'taming' or 'feminizing' her serial music, Lutyens thus carves out a place for herself as Arthur Rimbaud's magician, reflecting on the set text of 0 saisons, ô châteaux! and anticipating her later 'credo', in which she declares her music's allegiance with secret science rather than note counting or personal branding.
\end{abstract}

It has been lamented many times that twentieth-century music's most contested and significant phenomenon - modernism - and early twentieth-century British music do not sit comfortably together. All too often, music is perceived as either modernist (e.g., that of the Second Viennese School or other continental European or American avant-garde composers) or as British (e.g., that by Edward Elgar, Ralph Vaughan Williams, Gustav Holst, William Walton, or even Benjamin Britten). At best, the narrative of a time lag between continental modernism and a British modernism centred around Britten's operatic genre or the avant-garde of the New Music Manchester Group (here meaning composers Alexander Goehr, Harrison Birtwistle, and Peter Maxwell Davies from the mid-1950s onwards) was able to quell this problem - a problem that remains aggravated by the Dickensian notion of Britain as the 'land without music.' ${ }^{1}$ More recent attempts to bridge the gap between early twentieth-century modernism and British music have provided various solutions, but

Email: annika.forkert@bristol.ac.uk

1 Oscar A. H. Schmitz, Das Land ohne Musik. Englische Gesellschaftsprobleme, 3rd edn (Munich: G. Müller, 1914). Schmitz maintains that the lack of music in English society is a signifier of its lack of great individuals and individuality in general, which is created by an assumed mediocrity deeply rooted in the entire society (pp. 28-9). The study of British music has engaged with this verdict in various ways and the catchy title still enjoys frequent usage as a rhetorical device (cf. Andrew Blake, The Land without Music: Music, Culture, and Society in Twentieth-Century Britain (Manchester: Manchester University Press, 1997); Ruth Solie, 'No “Land without Music” After All', Victorian Literature and Culture 32/1 (2004); Jürgen Schaarwächter, 'Chasing a Myth and a Legend. The "British Musical Renaissance" in a "Land without Music", The Musical Times 1904 (2008)). 


\section{Forkert Modernist Enchantment in Elisabeth Lutyens's 0 Saisons, 0 Châteaux!}

one of the most obvious has not been applied rigorously: a look among British women composers. This is not to say that there are no studies about, for example, Ethel Smyth, Rebecca Clarke, Grace Williams, Elisabeth Lutyens, Elizabeth Maconchy, or Imogen Holst (in order of date of birth). Yet behind this lack of female composers in the study of British musical modernism lurks another powerful confrontation next to the one between modernism and British music - that of modernism and gender. Again, an outdated convention, this time of separating modern composers and modern women composers in British music (e.g., in Howard Hartog's textbook European Music in the Twentieth Century), rears its head, implying that women composers generally pursue different agendas in their compositions from modernist (men) composers, ${ }^{2}$ or that they are simply incapable of composing well in any style. In his review of Lutyens's 60th birthday celebrations that appeared in a 1966 issue of the BBC's The Listener, critic Stephen Walsh launched an attack in this vein:

Lutyens's music is among the least obviously appealing of any currently being written by leading composers of her generation. To my ears there has always been an element of dryness about her music, and it doesn't take an anti-feminist to suggest that it may have something to do with her sex. Female creative artists have always been rare - even in literature, the most immediate of the arts - while in music, at least, the gap between men and women in performance is small, if indeed it exists. Here again it is most measurable at the very top, where interpretation fades into visionary genius - a quality which is demonstrably anti-feminine. [...] And with Lutyens, even in maturity, it remains true that her music often makes structural points which are hamstrung by the ordinariness of her creative thought. ${ }^{3}$

Although this opinion sounds ludicrous to contemporary ears, the 'woman composer question', as Sally MacArthur has called it, has still not been resolved, despite several waves of feminism and their different strategies to tackle it. ${ }^{4}$ This article suggests that the main reason women composers have not been considered as salutary British modernists is that early twentieth-century modernism is still commonly understood as a man's world. ${ }^{5}$ In order

2 Anthony Milner, 'English Contemporary Music', in European Music in the Twentieth Century, ed. Howard Hartog (London: Penguin, 1957, 1961). (The edition of 1975 replaced Milner's chapter with one by Hugh Wood, which discusses works by a number of British composers - among them Elisabeth Lutyens as the only female composer on equal footing.)

3 Stephen Walsh, 'Music Last Week', The Listener, 8 December 1966, 869.

4 Despite Marcia Citron's positive assessment of the situation of women in music in the twenty-first century (Marcia Citron, 'Women and the Western Art Canon: Where Are We Now?', MLA Notes 64/2 (2007)), the 'woman composer question' has refused to go away (Sally MacArthur, 'The Woman Composer, New Music and Neoliberalism', Musicology Australia 36/1 (2014)).

5 My principal argument only appears to depart from Ellie M. Hisama's claim that 'the aesthetic and techniques of musical modernism are not inherently misogynist, but [...] modernism indeed provides a space for forms of expression by women' (Ellie M. Hisama, Gendering Musical Modernism: The Music of Ruth Crawford Seeger, Marion Bauer, and Miriam Gideon (Cambridge: Cambridge University Press, 2001), 11). In fact, I agree with Hisama that there is nothing wrong with modernism itself, but more space for women composers is needed in the canons of British musical modernism. 
to validate this claim and at the same time cut out a working definition of modernism, we can look to modernism's personnel (and in extension, its canons) as well as its aesthetics and criticism.

'High' modernism's peer groups in the arts, literature, and music are populated with alpha males such as Wyndham Lewis for the Vorticists, Ernst Ludwig Kirchner for Die Brücke, Filippo Tommaso Marinetti for the Futurists, or Arnold Schoenberg and Anton Webern for the Second Viennese School. Even a popular survey of musical modernism, Alex Ross's The Rest Is Noise, cannot break free from this impression: the only woman composers preceding late twentieth-century modernists are Alma Mahler (albeit merely in her role as Gustav's wife and an unreliable biographer), Germaine Tailleferre, and Ruth Crawford Seeger. ${ }^{6}$ Needless to say, important female 'sidekicks' of at least Mahler-Werfel's stature were affiliated with early twentieth-century modernist groups. Futurist Mina Loy, vorticists Helen Saunders and Jessica Dismoor, Schoenberg's librettist of Erwartung, Marie Pappenheim, or his pupils Natalie Prawossudowitsch and Dika Newlin, to name but a few, bore the flame for women modernists in some of high modernism's hothouse environments. Yet the canons of modernism (here meaning a mostly high-brow response to the perceived dissolving of tonality in the later nineteenth and early twentieth century) are still more often than not assembled from men, from continental European and American composers' works, and from masculine attributes ascribed to the included pieces. Richard Taruskin's fourth instalment of The Oxford History of Western Music is representative of the lack of women composers as well as of British composers generally. Instead of opening the modernist canons, it projects 'maximalism', an accelerated intensification of romanticist aesthetics as well as orchestral forces, volume, or meaning, onto modernism, with the result that both the composer of the gigantic Gurrelieder, Schoenberg, and the composer of miniature orchestral pieces, Webern, remain at the centre of the maximalist canon, as if the seal of quality was to be won in a competition for the most extreme quantity of bars and parts (a reading which does an injustice even to Schoenberg and Webern themselves). ${ }^{7}$

Meanwhile, a more parochial ongoing discourse about musical modernism in Britain is in danger of overlooking some of its most promising (women) modernists. Of these, the composer with the most obvious modernist credentials (in the provocatively reductive sense that her music is serial, i.e., has emancipated its pitch content from tonal regulations) is Elisabeth Lutyens - one of the earliest dodecaphonists in the country and incidentally the only female subject of a chapter in Matthew Riley's trailblazing collection British Music and Modernism. 1895-1960. ${ }^{8}$ Lutyens's works can flag up modernism's gendering problem while simultaneously bridging the gap between modernism and British music. This article examines different layers on which Lutyens's music engages with serialism (a dominant continental composition technique of her time and her composition process of choice for

6 Alex Ross, The Rest is Noise (New York: Picador, 2007).

7 Richard Taruskin, Music in the Early Twentieth Century. The Oxford History of Western Music, vol. 4 (Oxford: Oxford University Press, 2010), 5. Cf. chs. 1, 6, 12.

8 Laurel Parsons, 'Early Music and the Ambivalent Origins of Elisabeth Lutyens's Modernism', in British Music and Modernism. 1895-1960, ed. Matthew Riley (Farnham: Ashgate, 2010). 
her concert music) and how her engagement with it was read in both her critical and her analytic reception. Against the resulting entanglement of gender and composition technique, my argument sets the idea of 'magical serialism' in Lutyens's music, which is supported by choices in the texts of her settings, in particular in her cantata for soprano, mandolin, harp, guitar, and strings, O saisons, ô châteaux! of 1946. This work serves as the central case study for this exploration of Lutyens's transcendence of a superimposed masculinity of modernism. Although it is a relatively early piece in her official oeuvre, it can stand as representative of her best compositions, having frequently been singled out as one of her finest works and having been allocated more space in her autobiography than many other works. ${ }^{9}$

\section{The problem of the woman serialist}

The aversion to the stereotypical woman composer expressed in Stephen Walsh's earlier quote is couched in an ideology which portrays female composers as 'dry', 'hamstrung', and 'ordinary' (the rest of his review making it clear that Walsh does not level this accusation only at Lutyens's serialism, but also at a young Annea Lockwood's music). Men composers, by contrast, are credited with the ability of being a 'genius'. Walsh's woman makes a good performer or a muse owing to her 'ordinariness' and, presumably, her sensitivity, but the 'very top' field of creation is reserved for mature, visionary, and above all male creative thought. (Coincidentally, a book like Ross's popular twentieth-century music survey, although critical of this idea, repeats it: his twentieth-century women can be teachers, performers, librettists, and wives, but rarely composers in their own right.) Walsh's opinion merely copies that of his prominent romanticist predecessor Jean-Jacques Rousseau, who sought to separate genius and femininity forever by claiming that women

can acquire a knowledge [...] of anything through hard work. But the celestial fire that emblazens and ignites the soul, the inspiration that consumes and devours [... ], these sublime ecstasies that reside in the depths of the heart are always lacking in women's writings. These creations are as cold and pretty as women; they have an abundance of spirit but lack soul; they are a hundred times more reasoned than impassioned. ${ }^{10}$

Walsh may have been in exalted historical company, but the expression of his worldview still provoked a strong response by pianist Susan Bradshaw and composer Richard Rodney Bennett in the following issue of The Listener, where they maintained that Lutyens's O saisons ô châteaux! (among other pieces) revealed the composer's 'intensely romantic and poetic

9 For example, in Robert Saxton, 'Elisabeth Lutyens', New Music 88 (1988), 11.

10 Jean-Jacques Rousseau, 'Letter to Mr d'Alembert' (1758), trans. and quoted by Marcia Citron in 'Women and the Lied, 1775-1850', in Women Making Music, ed. Jane Bowers and Judith Tick (Champaign, IL: University of Illinois Press, 1986), 225 (referenced in Christine Battersby, Gender and Genius: Towards a Feminist Aesthetics (London: Women's Press, 1989), 36). 
spirit. ${ }^{11}$ Walsh in turn responded in the same issue with the clarification that 'the gist of my argument was that although women made excellent artist-technicians (at least as good as men), there was a certain quality of femininity which made it unsuited to creative art at the highest level'. ${ }^{12}$ Admitting that his remarks had 'landed [him] in pretty hot water', Walsh refrained from reviewing another Lutyens piece for The Listener until his thoroughly positive preview of her charade Time Off? Not a Ghost of a Chance! in 1972. ${ }^{13}$ His argument, as he maintained, was indeed general, insofar as his opinion applied not just to contemporary women composers, but also potentially to women composers of all times, with a rigid and traditional set of characteristics attributed to 'feminine' and 'masculine'.

In this world, it does not matter whether a woman composes a romantic symphony or a twelve-tone cantata - the results will most likely be bad music, because in composing she has disrespected her natural boundaries. Where a relatively new and contested way of organizing pitch enters into this mix, things become more complex. A snippet in The Western Morning News from a review of the 1947 concert, in which Lutyens's O saisons, ô châteaux! was premiered, illustrates additional problems with form, genre, and idiom:

Of Elisabeth Lutyens's setting for strings, harp, mandolin, and guitar of a poem by Arthur Rimbaud, one felt that a maximum of means was used to produce a rather meagre effect. Miss Field-Hyde sang the difficult vocal part with skill and assurance. ${ }^{14}$

As short as it is sharp, this anonymous review of the piece's 1947 premiere in the Wigmore Hall London criticizes a perceived failure to write for slightly larger forces ('maximum of means') in an appropriate idiom. Again mirroring Rousseau, the critic felt that Lutyens's work in serialism resulted in a 'meagre effect' (Rousseau's 'more reasoned than impassioned'), although details of this effect are not elaborated on. Despite its focus on the effect of the music, and not on the composer's gender, the review is reminiscent of Walsh's more general attack on Lutyens's credentials: that larger (albeit still chamber) forces would be deployed by a woman composer, only to fail to produce what we could call a masculine effect because it is not in a woman's nature, chimes with Walsh's complaint. Half jesting, Grace Williams, too, confirmed the existence of this crippling stereotype as late as 1961: in a short and throughout critical symposium of women in music in The Composer, she wrote that the last of 'three things I covet from a man composer' is 'his freedom to write a molto barbaro movement and have it regarded as just part of his nature and not in any way abnormal. ${ }^{15}$ The anonymous Western Morning News critic's verdict could be traced back to conclusions such as Walsh's: that by composing, women per se transcend their natural limits and that, consequently, no adequately sounding result can be produced in a woman's writing for orchestra. Likewise, the score's apparently 'meagre' effect in performance is a reminder of his verdict of dryness and

11 Susan Bradshaw and Richard Rodney Bennett, 'Elisabeth Lutyens. Letter to the Editor', The Listener, 29 December 1966, 969.

12 Stephen Walsh, 'Music Last Week', The Listener, 29 December 1966, 977.

13 Cf. Stephen Walsh, 'Elisabeth Lutyens's “Time Off?”, The Listener, 2 March 1972, 284.

14 Unsigned, 'Our London Letter. Gerald Cooper Concert', The Western Morning News, 13 February 1947, 2.

15 Elizabeth Maconchy et al., 'A Short Symposium of Women Composers', Composer 6 (1961), 21. 
'ordinariness'. Both critics may have used Lutyens to muddy the waters of two contemporary issues: 1) a challenge by women composers, who had begun to take on British music life, not least in efficient collaborative efforts such as the MacNaghten-Lemare concerts; and 2) the provocation which an advanced idiom (in the case of Lutyens's Cantata, twelve-tone serialism, henceforth 'serialism') still emanated, as The Times's review of $O$ saisons's premiere shows: 'The plucked instruments were used mainly to add a shimmer to the string tremolandos, thus giving to the music a kind of iridescence which relieved its rather crabbed harmonic style. ${ }^{16}$

The composer's response to allegations of this kind was about as dry as Walsh found her music. She once said that the subject of women's music was one that had 'dogged - or should I say "bitched" - me all my life.' ${ }^{17}$ In a conversation with Murray Schafer, she asked 'Is there such a thing as feminine music?' only to answer herself 'I don't think so.' ${ }^{18}$ This sentiment implies a larger point, which was shared by prominent contemporaries such as Elizabeth Maconchy, who complained that 'it is a mistake to divide composers into men and women as if the music they write is necessarily different. If there is a difference, it is something far more subtle than the conventional idea of "masculine" or "feminine" music. Can any honest and intelligent listener who does not know already tell which it is? ${ }^{19}$ Rephrased as a thought experiment, Maconchy's argument is twofold: 1) given an unknown piece of music, listeners would struggle to tell whether it was written by a woman or a man; and 2) the question whether the composer is a woman or a man is the wrong approach to start with. The logical consequence for her and Lutyens was what later feminists might consider a nearly anti-feminist rejection of the term 'woman composer' and the stereotypical characteristics attached to it. The reason for this rejection, however, was Maconchy and Lutyens's realization that 'woman composer' was not simply a neutral opposite of 'man composer', but also 'a kind of artist that is distinct and clearly different from the great artist', ${ }^{20}$ or, as Lutyens put it: "I suppose "masculine" is supposed to mean strong and decisive and "feminine" weak and charming. But I don't find that necessarily holds true of either sex. ${ }^{21}$

Even when the contested term itself was not critiqued, there was still room for stereotyping. In a 1950 The Listener article celebrating a forthcoming programme dedicated to Lutyens's music, John S. Weissmann claimed that O saisons, ô châteaux! possessed 'a certain transparency of texture and a conspicuous lightness of touch' and that Lutyens's defining difference to other dodecaphonists was 'her intuition, her personal approach' and her 'impressionistic quality. ${ }^{22}$ Although the critic took pains to stress her intellectuality and individuality, the specific feature of transparency here is tied to a haptic, physical quality - in effect the proverbial woman's

16 Unsigned, 'Gerald Cooper Concert', The Times, 12 February 1947, 6.

17 Elisabeth Lutyens, 'Divide and Misrule' (1972), quoted from Rhiannon Mathias, Lutyens, Maconchy, Williams and Twentieth-Century Music: A Blest Trio of Sirens (Farnham: Ashgate, 2012), 155.

18 Elisabeth Lutyens and Murray Schafer, 'Elizabeth Lutyens', in British Composers in Interview, ed. Murray Schafer (London: Faber \& Faber, 1963), 104.

19 Maconchy et al., 'A Short Symposium of Women Composers', 20.

20 Rozsika Parker and Griselda Pollock, Old Mistresses. Women, Art and Ideology (London: Pandora, 1981), 114, my emphasis.

21 Lutyens and Schafer, British Composers, 104.

22 John S. Weissmann, 'The Music of Elisabeth Lutyens', The Listener, 3 August 1950, 177. 
touch. The implications of this haptic resonance become clearer when compared to a roughly contemporary review of a piece with certain similarities to $O$ saisons $\hat{o}$ chateaux! such as Webern's op. 24. Webern's Concerto and Lutyens's Cantata, apart from being serial, both feature a chamber ensemble and represent important milestones in the respective phases of their composers' careers. Where Webern's transparency is concerned, however, this is expressed in a different context and language:

In its glorification of the interval, its crystalline transparency [... ], its utter and final renunciation of nineteenth century [sic] subjectivism, its extremely subtle dynamic and color (Klangfarben) differentiations, its unequivocal formal definition, all embraced by Webern's innate, highly personal lyricism, the Concerto has become one of the important points of departure for a whole new generation of composers. ${ }^{23}$

Webern's Concerto defines its composer as intellectual rather than haptic, as high modernist ('renouncing of nineteenth-century subjectivism') rather than Weissmann's 'impressionist', and as Taruskinian maximalist rather than miniaturist. ${ }^{24}$ The difference between the imagined masculine and feminine attributes of composers runs along the lines of a masculine intellect capable of creating intelligent and stimulating music and a feminine mind that is at its best when relying on its body, either as a performer (Walsh) or as a composer of music with a haptic quality (Weissmann). If the feminine mind oversteps these limitations by seeking to compose in a cerebral technique, its creations tend to be 'dry' (Walsh). It must be noted that all these definitions and attributions of masculinity and femininity can only ever convince to a degree, but not so much because they are obsolete today, but because they are fraught with contradictions. Thus, the male genius has important attributes of stereotypical femininity, such as an excess of sexuality and sensitivity, up to and including hysteria, but the female hysteric is never portrayed as a genius. The stereotypical female is limited by her role in physical procreation, but it is the male genius that transcends his sexual drive to procreate intellectually. Male genius is like a woman, but never is woman. ${ }^{25}$ In this article I do not attempt to play devil's advocate by upholding an imaginary divide between masculine and feminine attributes. The price the following thoughts pay for this refusal is that the divide retains its contradictory vagueness.

Lutyens's struggles with this conservative side of contemporary British music criticism relaxed over time as a greater number of informed reviews of her music began to appear, and as more fellow twelve-tone composers emerged. Yet to her music have not disappeared. ${ }^{26}$ For example, a very different sort of masculinity has been targeted in one of the most canonical texts of the New Musicology, Susan McClary's Feminine Endings. Although one could argue

23 Gunther Schuller, 'Review: Konzert, Op. 24. Für Flöte, Oboe, Klarinette in B, Horn in F, Trompete in C, Posaune, Geige, Bratsche, \& Klavier by Anton von Webern', Notes, Second Series, 17/1 (1959).

24 Taruskin, Music in the Early Twentieth Century, ch. 6.

25 Battersby, Gender and Genius, 3.

26 For such reviews, cf. Anthony Payne, 'Lutyens's Solution to Serial Problems', The Listener, 5 December 1963, 961, in which he credits Lutyens with solving issues thrown up by Webern's serialism. Gerald Larner, 'Frozen Music. Elisabeth Lutyens at 60', The Listener 24 November 1966, 784, seeks to defend a 'static' element in her music as 'pure mood'. 


\section{8 $\mid$ Forkert Modernist Enchantment in Elisabeth Lutyens's 0 Saisons, 0 Châteaux!}

that through the utilization of a putatively gender-neutral system of rules and regulations for this most absolute of absolute musics, serialism does away with prominent 'feminine endings' in music - feminine second themes, sweetness or simplicity of melody in tonal music, or even the madwoman's hysteria in Schoenberg's atonal music - this is not how feminist musicology has viewed it. Rather, McClary claims that the neutrality of serialism's collection of rules is a powerful illusion, because all it really demonstrates is the male genius taking control again:

From this moment on [the invention of Schoenberg's twelve-tone system], the rational frame guaranteeing social order comes to permeate the dissonant discourse of the madwoman, and the chromaticism of feminine sexual excess no longer poses a threat: henceforth it is appropriated - even guaranteed - by the highest achievement of intellectual discipline. ${ }^{27}$

In other words, male genius has, once again, successfully turned into great art those very qualities that limit women. Lutyens's music, variously labelled as dry or haptic, miniaturist or impressionist, seems to sit on the fence between the more traditional verdicts of her British critics and a later feminist rejection of serialism as a manipulative masculine exercise straddling feminine 'excess' and masculine 'genius' - Lutyens is damned if she does and damned if she doesn't write serial music. Post-McClary then, paradoxically, we seem under no less pressure to justify a woman composer's exclusive use of this compositional idiom than of tonality. In theory and practice, any composer, female or male, could use serial techniques in different ways and to different degrees, but for marginalized groups such as women composers, this decision can introduce an additional dilemma: is she a mere imitator if she does, or is she a romantic miniaturist if she does not? Lutyens appears to have gone all the way by adopting a technique which during her lifetime would remain firmly associated first with the Schoenberg school and then with the New Manchester Group. Although she claimed time and again that she had invented her own version of serialism long before she knew any by the Second Viennese School, it was by no means inevitable that she would stick with it as consistently as she did in her concert and stage music. ${ }^{28}$ This decision may have helped to establish her reputation of the English rebel composer in the long run (as opposed to a possible world in which she would have continued to compose in her pre-1939 idiom), but it also exposed her music to comparison with an influential and notorious set of male composers - first among them Schoenberg, Alban Berg, Webern, and René Leibowitz and Ernst Krenek (the latter two additionally having produced twelve-tone textbooks and analyses in French and English in the 1940s). Always keen to stress her own individuality and that she never studied with a teacher from the Viennese circle, Lutyens felt she had to walk the line between charges that she lacked originality (where she was perceived to follow too closely in

27 Susan McClary, Feminine Endings. Music, Gender, and Sexuality (Minneapolis, MN: University of Minnesota Press, 1991), 108-9.

28 This excludes many of her scores for film and television. On her 'invention' of serialism, see for example, Lutyens, $A$ Goldfish Bowl (London: Cassells, 1972), 167-8, 213; eadem, 'A Working Lifetime', The Listener, 8 July 1971, 57; eadem and Bernard Palmer, 'Interview', 1969 (www.bbc.co.uk/programmes/p02kycf4); eadem and Robert Saxton, 'Elisabeth Lutyens at 75. An Interview with Robert Saxton', The Musical Times 122/1660 (1981), 369. 
the footsteps of the larger Viennese circle) and that she lacked coherence and a justification for composing serial music (even though she didn't).

That she was acutely aware of this dilemma's first horn is evidenced not only by her countless comments on the originality of her serialism, but also, as the later analytical section of this article shows, by her blatantly obvious disregard for some conventions of serialism as applied by the Schoenberg circle. This attempt has created problems for feminist readings of her music, and particularly of O saisons, ô châteaux!, which have had to argue that Lutyens wanted to 'feminize' or even 'tame' her serialism in this piece to escape the comparison with serialism proper. ${ }^{29}$ More than claiming that her idiom is a 'personal brand' (which is certainly true for any composer), ${ }^{30}$ this argument of feminization opens, I suggest, a vulnerability prone to be attacked by a conservative historiography interested in keeping the canons of modernism exclusive, meaning here exclusively masculine. As I will show in the rest of this and the following section, the feminization argument is also unnecessary because of the ideology Lutyens herself provided to escape the second horn of her dilemma (charges of incoherence and random application of serialism). That is to say, she was no less aware of the other extreme: that a twelve-tone composer without some kind of structural ideological foundation to justify and consolidate their serialism would have problems being taken seriously; and to be taken seriously - to be a professional - was most important to her.

Her thoughts on what mattered about her own 'brand' of serialism and music more generally - that is, the aesthetic glue, so to speak - can be found scattered in her many writings, interviews, and, in a slightly more condensed form, in her autobiography, and taken together, these dispersed thoughts concern the magical and numerological attributes of music. Over a long career, her views slowly crystallized into the belief that 'music and art are more allied to religion and magic, meaning neither creed nor voodoo, than elementary arithmetic or science (so often inaccurately aped by composers), which has a different function. ${ }^{31}$ And in no other early piece is this credo more ingrained than in the cantata O saisons, ô châteaux!. While the next section examines the aesthetic implications of Lutyens's claim for music's magic in her choice of texts, its strategical advantages for her dilemma are obvious already. If Lutyens's claims for an aesthetic ('magical'), rather than technical ('note-count'), closeness to the Viennese modernists can be justified, she can be shown to successfully straddle originality and technical soundness.

\section{Magical texts and contexts}

That Lutyens felt an urgent need to declare her ownership of serialism is clear from the above statements and confirmed in the anecdote of her pretence to have wondered about the

29 Sally MacArthur, Feminist Aesthetics in Music (Westport, CT, and London: Greenwood Press, 2002), 100.

30 Anthony Payne, 'Lutyens, (Agnes) Elisabeth', in The New Grove Dictionary of Music and Musicians. vol. 15, 2nd edn, ed. Stanley Sadie and John Tyrrell (London: Macmillan, 2001), 389.

31 Lutyens, Goldfish, 305. 
composer of Freischütz writing such strange music upon hearing her first Webern piece. ${ }^{32}$ But instead of responding by 'feminizing' her music and thus becoming a 'woman composer', Lutyens sought to enchant serialism. With this idea she is in exalted company. Apart from Aleksandr Skryabin, Crawford Seeger, John Foulds, and many other composers, Webern and Schoenberg - the latter in his role of the 'lawgiver' of esoteric dodecaphony-sought to connect music and theosophical ideas; in this case those of gnosis and correspondence, as Wouter Hanegraaff has argued with regard to the Viennese set's shared aesthetics. ${ }^{33}$ Schoenberg, like Moses in Moses and Aron, is driven to despair by the unspeakability of the message of the new law he must communicate (gnosis), while Webern's writings and works operate with correspondences between row intervals, magical squares, and notions of Swedenborgian philosophy and Johann Wolfgang Goethe's 'Urpflanze'. ${ }^{34}$ Lutyens came to her magical credo on a much less straightforward and more painful path. Her experience of theosophy was not one of learned conversations and readings with educated friends resulting in the identification as a 'conduit of divine knowledge,, ${ }^{35}$ but of a hard and emotionally frustrating schooling by an institutionalized faith system, personified in her mother, Lady Emily Lytton, and Jiddu Krishnamurti, who as a boy ten years Elisabeth's senior was raised by C. W. Leadbeater and Annie Besant as the vehicle of the believed next coming of the spiritual world teacher Lord Maitreya. For the passionate teenager Elisabeth, theosophy meant suppressing her feelings in order to gain the acceptance of her mother and the strict Krishnamurti, as she would complain in her autobiography. ${ }^{36}$ Her spiritual career in the Theosophical Society culminated in her acceptance as a pupil of the Seventh Root Master Koot Hoomi and in becoming a co-mason in 1925. But the following year, she banished theosophy from her life and spiritual contexts from her music - apparently for good - and returned permanently to London to study composition and viola at the Royal College of Music.

Although this moment marks the end of her autobiographical account of spirituality in her life and music, an affinity for esoteric literature, if nothing else, stuck throughout her career. For one, she admired W. B. Yeats's poetry and had even met the poet when he visited her father, Sir Edwin Lutyens, in the later 1920s. ${ }^{37}$ Yeats himself had defined his relationship to magic in a kind of credo, not dissimilar from Lutyens's own:

I believe in the practice and philosophy of what we have agreed to call magic, in what I must call the evocation of spirits [...], in the power of creating magical illusions, in the visions of truth in the depths of the mind when the eyes are closed. ${ }^{38}$

\footnotetext{
32 Lutyens and Palmer, 'Interview', repeated in A Goldfish Bowl, 72, where she claims not to remember whether the piece in question was Webern's Bagatelles or Five Pieces.

33 Wouter Hanegraaff, 'The Unspeakable and the Law. Esotericism in Anton Webern and the Second Viennese School', in Music and Esotericism, ed. Laurence Wuidar (Leiden and Boston: Brill, 2010), 332.

34 Hanegraaff, 'The Unspeakable', 348.

35 Hanegraaff, 'The Unspeakable', 334.

36 Lutyens, Goldfish, 27-8.

37 Lutyens, Goldfish, 40. Although she found Yeats 'boring and pompous' on this occasion, she held his poetry in the highest regard (Lutyens and Saxton, 'Elisabeth Lutyens at 75').

38 W. B. Yeats, 'Ideas of Good and Evil', in Essays and Introductions (New York: Macmillan Company, 1961), 28.
} 
There are several examples of Lutyens choosing texts with mystical or magical undertones: the 'Invocation' and 'Night-Spel' sections of her Chaucer-cantata De amore (1957), Thomas Browne's quote from his astrological and mystical discussion of the quincunx in her piece of the same name (1959-60), Chaucer's translation of Boethius's astrology in The Country of the Stars (1963), the texts by the Sufi Abu Yazid Bistami and Arthur Rimbaud in Essence of Our Happinesses (1968), Lutyens's own libretto for the opera Isis and Osiris (1969), a selection of Yeats poetry in The Roots of the World (1979), and, earliest but no less important, Arthur Rimbaud's 'O saisons, ô châteaux!' for the eponymous cantata (1946). Lutyens's understanding of magic is opposed to Yeats's 'magical illusions'. As it presents itself in her set texts, this is a combination of art and speculative science, of alchemy and astrology, which deals with large questions such as time, death, or ritual. Frequently, her texts display an ambivalent relationship with nature; in the same sense that alchemy, with its drive to accelerate chemical reactions or create noble metals from base ones, can also overturn 'natural' oppositions, such as major and minor in music, light and dark, or masculine and feminine. In Isis and Osiris, for example, the god of writing, healing, and magic, Thoth, reassembles and resurrects the Nile god Osiris from his hacked corpse with spells and learning, allowing Egypt to prosper by bending the rules of nature. In $O$ saisons, $\hat{o}$ chateaux!, an accelerated reaction between serialism and a tonal heritage, between tone row and melody, and between feminine 'lightness of touch' and masculine 'transparency', characterizes Lutyens's experiments.

O saisons, ô châteaux! is Lutyens's first serial work for solo voice and orchestra, and the only substantial piece of concert music composed in her otherwise eventful year of $1946 .{ }^{39}$ She had left London in the spring to attend a concert of her works in Paris, organized by the British Council, and returned full of energy, if suspicious of serialism's popularity in France:

Among the young composers in Paris, 12-tone music was, by then, completely accepted so that I lost the sense of utter isolation I had felt in musical England. However, I amicably disagreed with Leibowitz for making an academicism of a language still being formed. The implications to be derived from the music of Webern had hardly begun, and I felt it was much too early to write a lexicon of grammar, as he was doing.

Certainly that professional trip to Paris was like a shot of adrenalin, renewing my health, restoring my confidence and morale, and infecting me with new hope and optimism for the future. I have always felt England to be part of Europe, especially musically, and now felt re-joined to the cultural past with new allies for the future. ${ }^{40}$

39 Chamber Concertos nos. IV and V are variously dated around 1946/7, but are not mentioned by Lutyens in the corresponding chapter of her autobiography.

40 Lutyens, Goldfish, 165. Although no 'lexicon of grammar' by Leibowitz exists, Lutyens may here be pointing to his treaty Qu'est-ce que la musique de douze sons? Le Concerto Pour Neuf Instruments op. 24 d'Anton Webern (Liège: Editions Dynamo, 1948) or his Introduction à la musique de douze sons. Les Variations Pour Orchestre op. 31 d'Arnold Schoenberg (Paris: L'Arche, 1949). 
Lutyens's dismissal of a 'grammar' of serialism as premature aims at Leibowitz's writings of the time, which were concerned with Schoenberg's op. 31 and Webern's op. 24, but more importantly spells out her doubts about laying bare its secrets in a systematic, comprehensible, and generally available form. ${ }^{41}$ If dodecaphonic magic was to keep its fascination, it could not be for everyone - a thought deeply inscribed also in Rimbaud's poem, as this section will argue. As 1946 neared its end, however, Lutyens's optimism about being part of a panEuropean serialism evaporated, as she found herself pregnant with what would have been her fifth child and gave in to the 'obvious, sensible advice' of her mother, her doctor, and her husband Edward Clark to have an abortion. ${ }^{42}$ Returning home from hospital, she finished O saisons, ô châteaux!, a commission from Gerald Cooper for his concert series in the Wigmore Hall, where it was premiered in February 1947. According to Lutyens's recollections in her autobiography, the work took its inception from her acoustic intentions, and not from the piece's context or her personal circumstances. This way of picking texts after the first musical sketches stayed with her - Wittgenstein's Tractatus Logico-Philosophicus for her later piece of the same name was suggested by Edward Clark and Terence Tiller when she asked for 'something accurate and impersonal, but not religious' to go with the new piece. ${ }^{43} \mathrm{O}$ saisons blows into the same horn of her post-theosophy claim that music must not be entangled with personal, religious, or amorous feelings: ${ }^{44}$

I had conceived the piece, even heard the complete sound - in form and timbre and begun the writing whilst still searching for the right words. I was hearing a soprano voice, of the calibre of Oda Slobodskaya's [an acquaintance of Lutyens's, famous for her high register], in a soaring lyrical lament, supported by all variety of string sounds - like an enlarged, amplified guitar. Accidentally meeting John Davenport [the piece's dedicatee] in the Gin and Gumboot and telling him of my word-search, he immediately, with his intuitive understanding, suggested the short Rimbaud poem O Saisons, O Châteaux!.. ${ }^{45}$

41 The esoteric Schoenberg perhaps felt something similar when he decreed that 'secret science is not what an alchemist would have refused to teach you; it is a science which cannot be taught at all. It is inborn or it is not there' (Arnold Schoenberg, 'The Blessing of the Dressing' (1948), in idem, Style and Idea (60th anniversary edition), ed. Leonard Stein (Berkeley: University of California Press, 1975), 386, quoted in Hanegraaff, 'The Unspeakable'), followed by Adorno, who lamented in 1955 that 'unfamiliar with the real accomplishments of the Schoenberg School and in possession only of the rules of twelve-tone composition, which have become apocryphal through separation from its accomplishments, these young people [young composers] amuse themselves with the juggling of tone rows as substitute for tonality, without really composing at all' (Theodor W. Adorno, 'The Aging of the New Music', in Essays on Music: Selected, with Introduction, Commentary, and Notes by Richard Leppert; New Translations by Susan Gillespie (Berkeley and London: University of California Press, 2002), 196).

42 Lutyens, Goldfish, 175-6.

43 Lutyens, Goldfish, 222 (italics original).

44 Cf. Lutyens and Schafer, 'Elisabeth Lutyens', 106-7: 'Music is simply organized sound, and if it is well organized it may have the power to produce emotions in the listener, but those emotions are not inherent in the music itself.'

45 Lutyens, Goldfish, 168. 
With a cantata set to a poem by the fashionable Arthur Rimbaud, Lutyens harnessed a 'French stimulus' and claimed her place in a long and illustrious line of Rimbaud settings. ${ }^{46}$ She (or Davenport) chose not the better-known version of the poem from the collection Une saison en enfer, ${ }^{47}$ but the version given below, which is one of three other, substantially differing, versions of this poem with an unknown date of conception.

O saisons, ô châteaux,

Quelle âme est sans défauts?

O saisons, ô châteaux!

J'ai fait la magique étude

Du bonheur, que nul n'élude.

$\mathrm{O}$ vive lui, chaque fois,

Que chante le coq gaulois.

Mais je n'aurais plus d'envie,

Il s'est chargé de ma vie.

Ce charme! il prit âme et corps,

Et dispersa tous efforts.

Que comprendre à ma parole?

Il fait qu'elle fuie et vole!

O saisons, ô châteaux!

Rimbaud's poetry was en vogue during the 1940s, providing the topic of Wallace Fowlie's reflection of the poet's life and works, a Hogarth Press translation of verse poems, and several editions of Enid Starkie's successful biography. ${ }^{48}$ The second edition (1947) of the latter, although just not yet published when Lutyens was composing the work, traces Rimbaud's interest in magic. Quoting this very poem in her chapter on the poet's disappointment after his stay in Paris, Starkie highlights elements of alchemy and magic in the series of poems written in $1872 .{ }^{49}$

46 Weissmann, 'The Music of Elisabeth Lutyens', 177. Rimbaud settings have otherwise tended to cluster around texts from the collections Illuminations (set by Britten, in Henze's cantata Being Beauteous (1963), or in Rihm's Départ (1988)) and Une saison en enfer (examples include Harold Blumenfeld's opera Seasons in Hell. The Lives of Arthur Rimbaud (1994) or Matthias Pintscher's opera L'espace dernier (2003)).

47 This version would have been available in collections for the enthusiast of poetry such as Rimbaud, Les plus belles ceuvres. Collection de textes français publiée sous la direction d'André Labarthe (London: Barnard \& Westwood, 1943), $147-8$.

48 Wallace Fowlie, Rimbaud: The Myth of Childhood (London: Dennis Dobson, 1946); Arthur Rimbaud, Selected Verse Poems of Arthur Rimbaud, trans. Norman Cameron (London: Hogarth Press, 1942); Enid Starkie, Arthur Rimbaud (London: Faber \& Faber, 1938, 1947, 1961).

49 Enid Starkie, Arthur Rimbaud, 2nd edn (London: Hamish Hamilton, 1947), 206-7. Nevertheless, it is highly unlikely that Davenport and Lutyens found the poem and this interpretation in this biography, as the first edition of 1938 does not contain these remarks and the revised edition was not published before 1947, when the piece had been written. 
'O saisons, ô châteaux!', in all its hermetic closedness, addresses magical practice and the magician in several ways. First, it features three keywords of magic: the poem's persona claims to have executed the 'magical study of bliss' ('J'ai fait la magique etude I Du bonheur, que nul n'élude'), and praises the 'spell' that takes soul and body, obliterating all efforts ('Ce charme! Il prit âme et corps I Et dispersa tous efforts'). ${ }^{50}$ It finally celebrates the 'Gallic rooster' in the verse 'O vive lui, chaque fois I Que chante le coq gaulois.' This symbol, although only vaguely associated with druidic beliefs through the homonymity of Gallus (Gaul) and gallus (rooster) in Latin, is still a national symbol of druidic France. Second, the prominent line 'O saisons, ô châteaux', which appears as opening, closing, and third line in the poem, seems to fulfil the function of this spell or incantation which obliterates all efforts, albeit indecipherable for the uninitiated (Schoenberg's 'secret science' comes to mind again here). Third, the last verse, 'Que comprendre à ma parole? I Il fait qu'elle fuie et vole!', not so much questions the usefulness of words or language, but seems to refer to that very secrecy of magical practices the uninitiated cannot understand the magician's speech, who thus gains splendid isolation, bringing to mind Lutyens's resistance to attempts by Leibowitz at setting down a 'grammar' of serialism.

Additional to these hints in its content, the poem's form is highly experimental. First, it has shed the traditional fixed verse form of its previous versions in favour of a 14-line structure, which is split into $2+1+2+2+2+2+2+1$ lines. Second, its rhyme scheme AA A BB CC DD EE FF A likewise rebels against traditional, more symmetric structures. In both categories it is the line 'O saisons, ô châteaux' which is directly responsible for the interruptions of verse and rhyme structures. Third, the poem is heterometric. The version used by Lutyens upon Davenport's advice is one made up of monostiches and distiches with six or seven syllables. While the last two occurrences of 'ô saisons, ô châteaux' appear as six-syllabled monostiche, its first occurrence is bound up in a distiche with the second six-syllabled line 'quelle âme est sans défauts?' The majority of lines, however, appear in seven-syllable distiches. According to Michel Murat, Rimbaud was complicating the poem further from version to version, with the one chosen by Davenport and Lutyens being the most complex and irregular one. $^{51}$

Thus, this version has 14 lines $(7+7)$, but it uses a highly irregular verse structure to obscure this fact. Next, its lines with seven syllables are in the majority, but by no means safe from interruption from six- or eight-syllabled lines. The mysterious anapaest 'O saisons, ô châteaux' is the most insistent of these. The poem makes use of a game with numbers on two levels, an idea that would undoubtedly have appealed to most composers interested in serialism (Schoenberg's numerology springs to mind). Particularly the elusive prominence of the number 7 would have delighted Schoenberg, standing as it does for perfection (seven spheres and planets, sciences in quadrivium and trivium, musical modes, strings on the lyre, and of course pitch classes in a tonal scale). Despite McClary's understanding of dodecaphony

50 Arthur Rimbaud, Rimbaud Complete. Volume 1: Poetry and Prose, trans. Wyatt Mason (New York: Modern Library, 2003), the four versions of the poem are on 356-60.

51 Michel Murat, L'art de Rimbaud (Paris: José Corti, 2002), 95-6. 
as a rule-bound, 'serene and orderly' taking back of control in music, ${ }^{52}$ its obsession with the possibilities of series of numbers and their transpositions, inversions, and retrograde inversions could as well be interpreted as a re-enchantment of music, the return to its alchemy - that is, to Pythagorean experiments with numbers and notes.

This re-enchantment, again, is only open to the initiated, those that, in Rimbaud's sense, have 'made a magical study of inescapable blisss. ${ }^{53}$ Without much doubt, Lutyens would have understood herself as one of those, and even the foremost in her country. If the composer was half as bitter in 1946 as she would claim in retrospect in A Goldfish Bowl, her identification with the figure of the Yeatsian magician in Rimbaud's poem is likely, despite her much later reminiscence about her first, non-textual intuition, which seeks to downplay the importance of her chosen poem. Like this magician, Lutyens imagined herself in a superior position due to her use of dodecaphony; a position, however, which made her (together with her husband Edward Clark) vulnerable to derision and lack of comprehension by British colleagues and critics:

I was soon to realize that we were both to be classified 'OUT' by the musical Establishment for backing the wrong horses - such as Schoenberg and Webern - and thereby setting ourselves outside the musical pale in the climate of musical England. [... ] To adopt a technique, like the 12-tone, associated with a German, Schoenberg (albeit that, earlier, I had thought I had 'discovered' it myself, from my study of Purcell), was 'mittel-European', un-English and iconoclastic. I was soon made to feel like a Communist before the Committee for Un-American Activities. [ . . . ] I don't forget those many who sneered and jeered over the years, only to change their tune and quickly jump on the band-wagon when the climate changed in England - even the critics realizing that being able to count to twelve - instead of seven (as in classical music) - was not an insuperable difficulty. [...] As Dallapiccola said to me, 'It is not a risk today.' Then, it most certainly was. ${ }^{54}$

Lutyens's set text was also a topic in later summative assessments of her music, with the work generally being viewed as one of her most important pieces. In a review of her œuvre on the occasion of her sixtieth birthday, Gerald Larner claims that the texts of O saisons, ô châteaux!, of the motet Excerpta Tractati Logico-Philosophici (Wittgenstein) for unaccompanied chorus, and of the part-song The Country of the Stars (Boethius) for unaccompanied chorus inspired music of constructional unity, music of a self-sufficient system or absolute singularity of mood, rather than sustained conflict and dialectical progress. ${ }^{55}$ It could be argued that Larner attempts to pull Lutyens across the imaginary divide of 'woman composer' and 'composer' with such praising observations as the 'constructional unity' and 'self-sufficient system' her

52 McClary, Feminine Endings, 108-9.

53 Rimbaud, Rimbaud Complete, 359.

54 Lutyens, Goldfish, 167-8 (italics in original). In this quote, the comparison between the communist and the serial composer stand out. Although the committee did not yet exist when Lutyens wrote the piece, the idea that both communism and serialism were perceived as the greatest dangers to Western civilization is striking.

55 Larner, 'Frozen Music', 784. 
(masculine?) set texts inspired in her mind. At the same time, the music's lack of 'conflict and dialectical progress' seems to thwart any claim to what has earlier been identified as 'genius'. Two further, posthumous, reviews agree that Rimbaud's poem is 'highly charged', presumably relating to the male genius's ability to channel feminine hysteria into a masterpiece. In the first of these two reviews, Brian Elias's introduction to a broadcast of Lutyens's works shortly after her death, this praise rubs off on the music: 'The work completely transcends its brief time span, \& by its extreme economy and taut control it transports the listener into a richly emotional world expressive of nothing but itself and the highly charged Rimbaud poem. ${ }^{56}$ Similarly to Larner's review, Elias claims that the music is inspired by - and profits from its text's concentration. Consequently, the music is able to unfold a large drama in only seven minutes' duration. This idea was taken up by Malcolm Hayes, who however shifted his gist slightly towards a more feminized reading of Lutyens's piece: '[it] subtly recalled Britten in its choice of text and scoring (the lady herself would have had something to say in reply to that remark, I do not doubt) but effortlessly met the claims made for it by Brian Elias in his introduction: the music perfectly caught the acute sense of beauty conveyed by Rimbaud's brand of highly-charged disembodied ecstasy. ${ }^{57}$ Here, Rimbaud's poetry is not only concentrated, but also 'disembodied' and ecstatic - both features of the male genius's ability to channel and transcend its feminine side, physicality and ecstasy. Lutyens herself is credited with portraying the beauty of this genius. According to Hayes, she manages this by 'subtly recalling Britten', by which he alludes to the latter's setting of Les Illuminations (1939). Hayes apparently knew Lutyens well enough to admit that to claim that she was not being entirely original in the Cantata would have provoked an unprintable response from the composer. Although he may have been intending it as praise, the music's alleged resemblance to Britten's and its 'catching' of the beauty of masculine genius Rimbaud's intellectual ecstasy succeed in limiting the piece's own claim to originality, yet again. There can be no doubt that Britten, by this time, had emerged as a leading figure of British music and that Lutyens's setting would provoke this comparison, but the previously lamented confusion over gender and genius here rears its head again. After all, both Rimbaud and Britten's own sexuality was not that of your everyday male procreating genius; and bringing Lutyens's piece in line with both certainly complicated matters more than drawing distinct and neat lines between the genders.

Lutyens's choice of text, then, binds together several components of a complex situation. While the text chimes extraordinarily well with her pessimistic evaluation of her own professional situation in 1946 as a serial composer in a musically conservative country, it also lays out her programme, or intention, for her chosen compositional technique - the enchantment of serialism. At the same time, she picked a text that critics came to read as an unusually fruitful choice in her œuvre, and stimulating her creative powers, which were not

56 Brian Elias, 'Introduction to O saisons, ô châteaux!' (for a memorial broadcast of Lutyens works, 8 December 1983), in Elisabeth Lutyens, Letters to Brian Elias, with related material, 1965-83. GB-Lbl Add. MS. 71114: 1965-83, fols. 215-16.

57 Malcolm Hayes, 'Music', The Listener, 5 January 1984, 28 (emphasis original). 
always perceived of as fully original. O saisons, ô châteaux! has as good as nothing in common with, for example, Schoenberg's contemporary and equally short cantata A Survivor from Warsaw, but this is partly because Lutyens has different considerations in mind: her choice of text announced her individual understanding of her distinguished but contested position in British musical life, and her complaint of having backed 'the wrong horses' can be read as a typical modernist composer's retrospect complaint. ${ }^{58}$ She considers herself the outsider par excellence - an English modernist woman composer. ${ }^{59}$

\section{O saisons, ô châteaux! and magical serialism}

By paying so much attention to the set text and invoking its repercussions in the following analytic observations of $O$ saisons, ô châteaux!, I go against what Lutyens would have wished. After her break with theosophy, she maintained that her music was expressive only of itself and did not carry extra-musical content or meaning. Her remark about beginning to compose the piece before finding the text must be read in this vein. What is more, it is conceivable that she regarded serialism in general as a failsafe way to achieve this independence in her compositions. Nevertheless, her later magical credo and, not least, the Cantata's music put this claim in context. As this section will argue, Lutyens's serialism in the Cantata is not 'feminized' - neither in Walsh's 'dry' sense, nor in MacArthur's defensive sense, which seeks to explain Lutyens's rebellion against an imaginary Viennese textbook. Serving this purpose, the following analytic observations address 'deviating' serial features, some of which can also be observed in works of the Schoenberg school. Among these is the dovetailing of rows (as in Webern's Piano Variations op. 27 no. 2) or the suspension of the 'correct' row order (as in Schoenberg's op. 33b). The aim here, however, is not to construct Lutyens as a 'good' follower of a 'correct' serialism, but to point out ways in which she bends an inherent rigidity in order to achieve a new magical notion of serial modernism in O saisons, ô châteaux! and thereby to transcend what she and her contemporaries perceived as the woman composer curse. Lutyens's speciality in this respect is repetition at different levels of the structure, which follow on from two other layers of row manipulation.

The row's Grundgestalt and the first burst of the vocal line present a reminder of its composer's first intuition of the piece as a lament (one of Lutyens's favourite tropes for her music for high voice, Examples 1a and 1b). In this respect the piece foreshadows such works as The Valley of Hatsu-Se (1965) in its virtuosic demands on the singer's range. In 1946, she was studying Dido and Aeneas (including the famous Lament from this opera) by Purcell, the composer whose string fantasias she claimed had given her the idea for her serialism. ${ }^{60}$

58 Lutyens, Goldfish, 168.

59 It could be added that she was an outsider even in terms of class. Born into an occasionally explosive marriage between middle and upper classes, her London life had been jumbled up during the war with the temporary evacuation of herself, Edward Clark, and their children to different places, and she emerged impoverished and resentful of her financial reliance on the upper-class parts of her family.

60 Parsons, 'Early Music'; Sarah Jane Tenant-Flowers, 'A Study of Style and Technique in the Music of Elisabeth Lutyens' (PhD diss., University of Durham, 1991), 165. 


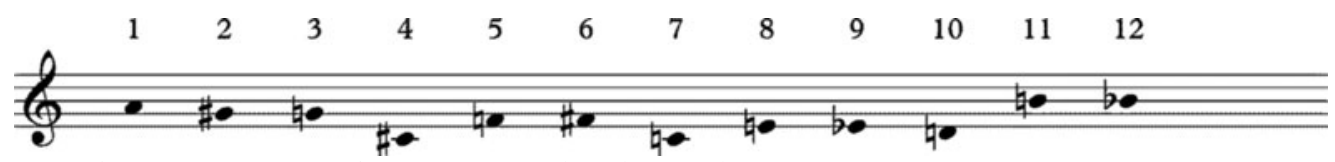

Example 1a O saisons, ô châteaux!, P-0 with order numbers.

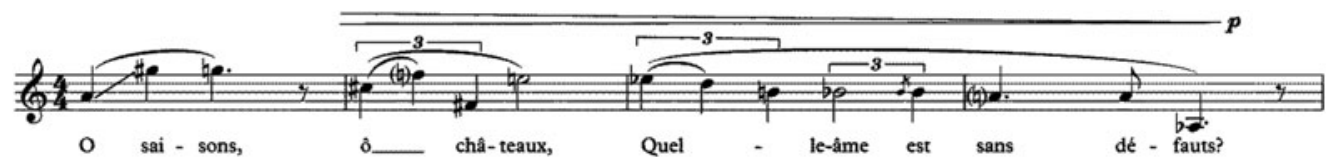

Example 1b O saisons, ô châteaux!, soprano, bb. 42-5. ๑ 1960 (renewed) EMI Mills Music, Inc. Exclusive print rights administered by Alfred Music. All rights reserved.

Indeed, the prominence of descending semitones in the row of $O$ saisons, ô chateaux! are reminders both of Lutyens's first intuition of a lament and of her occupation with Purcell's opera, in which a witch's evil magic destroys Dido and her lover's unity. ${ }^{61}$

Over the course of the composition of $O$ saisons, Lutyens changed her mind over the genre of this 'soaring lyrical' lament; she first considered it a serenade, and only later a

61 Note counting of this row reveals the following matrix, which is in itself of a certain beauty, with its pc 0 running diagonally through all transpositions.

\begin{tabular}{|c|c|c|c|c|c|c|c|c|c|c|c|}
\hline 0 & 11 & 10 & 4 & 8 & 9 & 3 & 7 & 6 & 5 & 2 & 1 \\
\hline 1 & 0 & 11 & 5 & 9 & 10 & 4 & 8 & 7 & 6 & 3 & 2 \\
\hline 2 & 1 & 0 & 6 & 10 & 11 & 5 & 9 & 8 & 7 & 4 & 3 \\
\hline 8 & 7 & 6 & 0 & 4 & 5 & 11 & 3 & 2 & 1 & 10 & 9 \\
\hline 4 & 3 & 2 & 8 & 0 & 1 & 7 & 11 & 10 & 9 & 6 & 5 \\
\hline 3 & 2 & 1 & 7 & 11 & 0 & 6 & 10 & 9 & 8 & 5 & 4 \\
\hline 9 & 8 & 7 & 1 & 5 & 6 & 0 & 4 & 3 & 2 & 11 & 10 \\
\hline 5 & 4 & 3 & 9 & 1 & 2 & 8 & 0 & 11 & 10 & 7 & 6 \\
\hline 6 & 5 & 4 & 10 & 2 & 3 & 9 & 1 & 0 & 11 & 8 & 7 \\
\hline 7 & 6 & 5 & 11 & 3 & 4 & 10 & 2 & 1 & 0 & 9 & 8 \\
\hline 10 & 9 & 8 & 2 & 6 & 7 & 1 & 5 & 4 & 3 & 0 & 11 \\
\hline 11 & 10 & 9 & 3 & 7 & 8 & 2 & 6 & 5 & 4 & 1 & 0 \\
\hline
\end{tabular}

Figure 1 O saisons, ô châteaux!, row matrix.

However, Lutyens does not make use of the hidden numerical possibilities of this matrix. This means that her row can be understood as a musical theme more than as an aggregate of motifs as is often the case in the matrices of the Viennese. 
Table 1 Sections of $O$ saisons, ô châteaux!.

\begin{tabular}{ccc}
\hline Section & Bars & Row transpositions of \\
\hline A & $1-41$ & $P, I$ \\
B & $42-64$ & $P$ \\
C & $65-90$ & $R, R I$ \\
A $^{\prime}$ & $91-122$ & $P, I$ \\
\hline
\end{tabular}

cantata. These terms, however, say more about her intentions than about the final shape. Her earliest ascription of the piece as a serenade is recorded in pencil on her manuscript and is also mirrored in the piece's texture and orchestration (plucked and submerged strings with a voice rising above them). ${ }^{62}$ Despite these similarities with the serenade of Viennese classicism and the (probably coincidental) fact that one of Schoenberg's earliest serial works was also of that genre (the Serenade op. 24 of 1923), Lutyens's final decision favoured the cantata. Unlike Schoenberg's choral A Survivor of Warsaw, Lutyens's piece leans towards the pre-1800 cantata with its combination of solo voice and instrumental, often chamber accompaniment. It borrows specifically from an English variant of the genre, which had split from the dominant Italian form, preferring less Arcadian and more profane texts with a freer form (usually binary) with instrumental ritornellos in accordance with the chosen text - all features that can also be found in O saisons, ô châteaux! ${ }^{63}$

Sarah Tenant-Flowers's analysis of the Cantata's serialism in her pioneering $\mathrm{PhD}$ thesis was the first to claim - correctly - that the piece is constructed serially throughout - an important statement as it allows us to assert Lutyens's loyalty to this technique and in consequence to unleash the full range of analytic tools for serialism onto the piece and, at the same time, acquits the composer from the crudest Rousseauvian accusation of the inability to compose a coherent piece of music. ${ }^{64}$ The instrumental introduction, the first of four sections, fulfils this promise to the greatest degree (Table 1). ${ }^{65}$

Each section uses different row transformations, and the return in $\mathrm{A}^{\prime}$ to prime $[P]$ and inversion $[I]$ material of the introduction A frames the two middle sections. Of these, section $\mathrm{B}$ only uses $P$ material and section $\mathrm{C}$ only retrograde $[R]$ and retrograde inversion $[R I]$

62 Lutyens, Elisabeth, Cantata for Soprano and Strings Opus 13: O Saisons, O Chateaux! (MS, November 1946, GB-Lbl Add MS 64639), 2 recto/verso; Colin Mason characterized it as an 'extended song of interesting and subtle sonata-like form' in his review of the miniature score for Music \& Letters 43/1 (1962), 91.

63 Colin Timms et al. 'Cantata', in The New Grove Dictionary of Music and Musicians, 2nd edn, ed. Stanley Sadie and John Tyrrell (London: Macmillan, 2001).

64 Cf. Tenant-Flowers, 'Lutyens', 173.

65 I deduce this four-section structure from the occurrences of row transformations. By contrast, Tenant-Flowers sees a 'basic ternary' structure of A (1-41)-B (42-64)-A' (65-90)-A" (91-122) and Vivienne Olive notes a five-part structure of I (Introduction, 1-41)-II (42-63)-III (64-90)-IV (91-108)-V (Coda, 109-22). (Cf. Tenant-Flowers, 'Lutyens', 166, and Vivienne Olive, 'Elisabeth Lutyens fällt vollkommen aus dem Rahmen', in Annäherung: An sieben Komponistinnen. IV, ed. Renate Matthei and Brunhilde Sonntag (Kassel: Furore, 1988), 40. 
material. With the beginning of section B and the soprano's deployment in b. 42, irregularities break up the neat serial structure of the previous section A. Although this section B only uses $P$ transpositions, it deploys Lutyens's strongest magical strategies in short succession: dovetailing and rotation of rows, omissions and additions of pitch classes (henceforth pcs) in row occurrences up to the splitting of rows, and repetitions within rows.

First, Lutyens frequently dovetails rows. A first instance occurs as early as bb. 23-4 (still in section A), where the cello oscillates between different consecutive pitches of two different $I$ transpositions in a tremolo. The major occurrence in section $\mathrm{B}$ is in b. 45 , which ties together the end of the soprano's first phrase, in which pcs A and Ab acted as nos. 1 and 2, with the beginning of the next transposition, in which the same pcs represent 11 and 12 (Example 2). This causes this next occurrence of the row to be a rotation (order nos. 11, 12, 1, 2, 3, 4, 5, $6,7,8,9,10)$. The 'switch' takes place in an exposed position - the soprano is accompanied only by the celli and basses' pedal point.

In bb. 51-3, dovetailing even leans over into disaggregation with its generous but apparently random spreading of pcs from P-3 and P-5 (Example 3). Vivienne Olive, the piece's earliest analyst, diagnoses that this moment 'breaks the row's logic and instead works with motivic figures on a more flexible basis'. Furthermore, she observes 'seemingly "irrational" interjections, which elude a "proper" analysis', that is, a simple note-count. ${ }^{66}$ Olive carefully skirts pejorative language with a high density of scare quotation marks, implying that these collapses of rule-bound serialism would hurt Lutyens's claim to high-quality serialism. What can be observed in these bars is that the row submits to the priority of a descend in all parts, particularly in the middle bar 52. (It is likely that the violas' E instead of the missing F on the third beat of this bar is owed to this need for the parts to descend.) Whether bb. 51-3 constitute a breakdown of the row, an extreme case of dovetailing, a disintegration into several pc collections, or a serial-tonal hybrid is a typical question in this piece and eludes a clear solution. It is, moreover, a moot question for Lutyens. The two transformations of the prime row running in tandem through the four string parts are not organized to elude or avoid a strict serial organization but to increase drama and remind listeners of the piece's lamenting character.

For the largest part, examples of dovetailing and rotation are normal occurrences in much serial music and leave the paradigm of the ordered set untouched. Lutyens, however, deploys a second layer of row manipulation, which interferes with the row's fabric. It also introduces an element of enchantment into the piece by means of a close connection of row manipulation and set text. This first covers the omission of one pc in an otherwise complete row in one part, which is then frequently added in another part. The first and crucial occurrence of this device is in the statement of P-0 in section B (bb. 42-4, cf. Example 2). Here, the soprano melody consists of order nos. 1, 2, 3, 4, 5, 6, and 8 , while guitar, harp, and strings already hold a pedal on nos. $6,8,9,10$, and 12 . This overlapping complementation (which even doubles some pcs), cannot hide the fact that nos. 7 and 11 are - on a superficial glance - missing from this set. However, both do appear eventually in the right moment in the row - that is,

66 Olive, 'Lutyens', 42, 45 (my translation). 


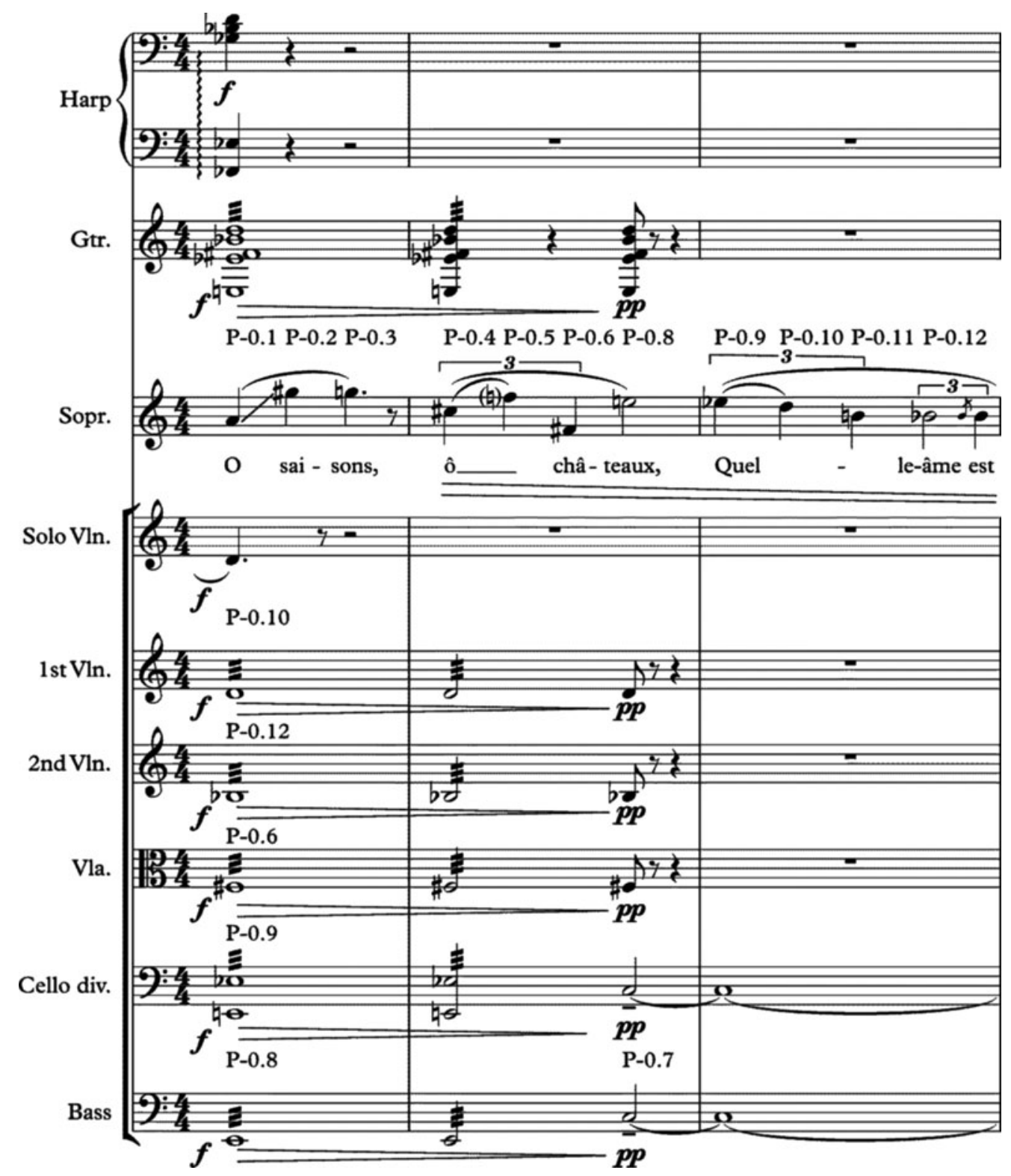

Example 2 O saisons, $\hat{o}$ châteaux!, bb. 42-7, with row transpositions and affiliated order nos. $\odot 1960$ (renewed) EMI Mills Music, Inc. Exclusive print rights administered by Alfred Music. All rights reserved.

simultaneous with the soprano's 6 and 10 . Yet no. 7 only appears in a dark and very quiet cello and bass pedal, which lasts for nearly four bars. That this particular order number is obscured so suspiciously here is hardly a coincidence: the soprano strides through the magic spell (the title line $O$ saisons, ô châteaux!), which itself lacks the seventh syllable (the poetic implications of which were discussed above). Although such omissions or hidden order numbers occur 


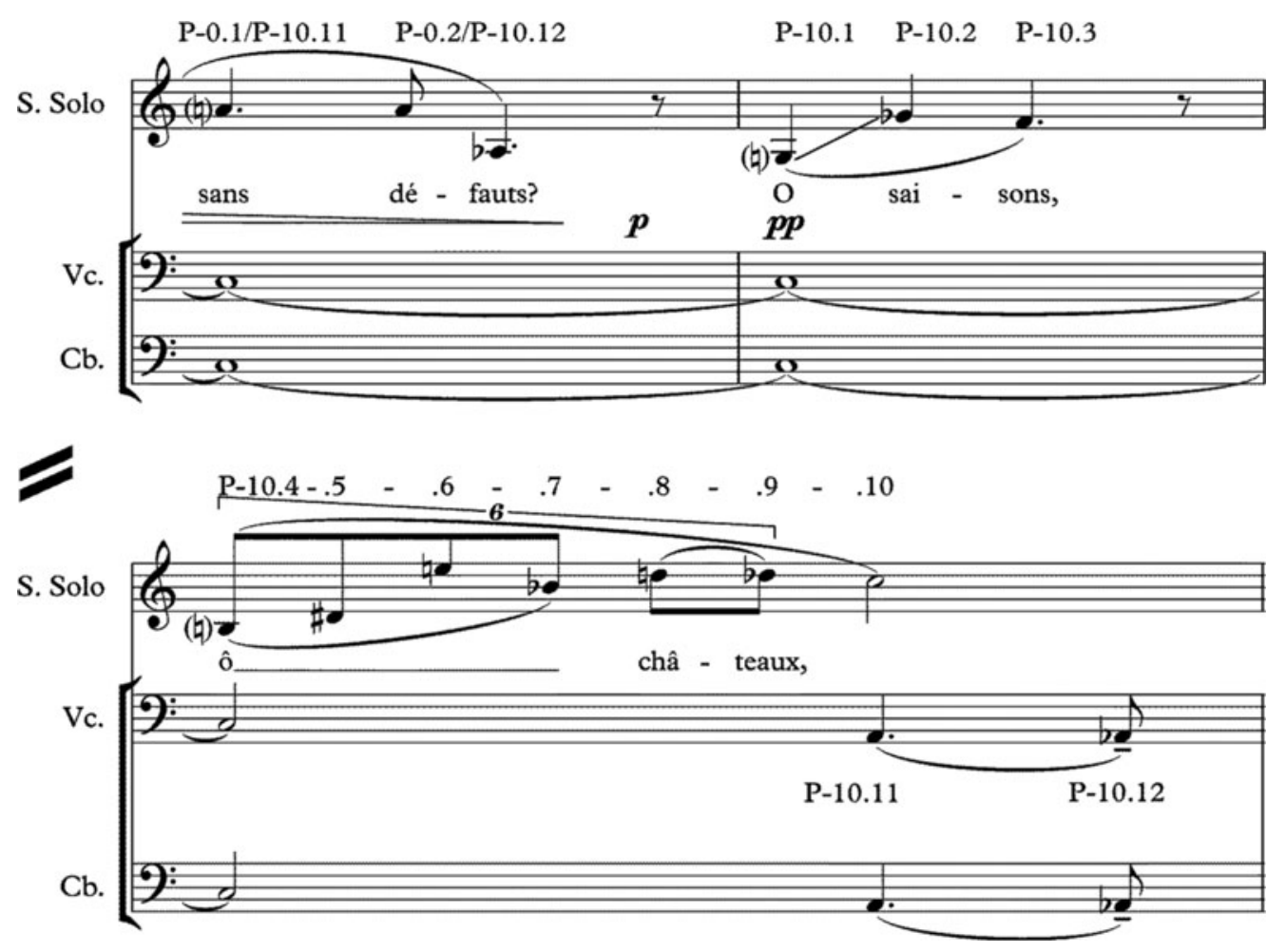

Example 2 Continued.

throughout the piece, the resulting subsets of the row more frequently miss no. 7 than other order numbers (bb. 64 [missing 1-5 and 7], 79-80, and 101 [missing 7 and 12]).

Second, and on the other end of the spectrum, on one occasion the soprano adds one tone to a row transformation, and again this 'transgression' is justifiable by reference to the poem. In b. 94, the soprano drops in a dramatic glissando down into a distinctly lower register for the exclamation 'Ce charme!' (Example 4). This is also the beginning of a new I transformation, in which the soprano part runs through the order nos. 1-10, while the ensemble plays with different sub-collections consisting of two pcs each. In b. 95, C $\sharp$, order no. 11, falls on the word 'charme' (spell); it splices the running row by perching between nos. 2 and 3 of the same transformation. This enrichment threatens the dominance of the row, but clearly the priority is to highlight the dynamic climax and a metric and register change. It provides a dramatic effect of this 'spell', which, according to Rimbaud's poem, 'tak[es] soul and body and dispers[es] all efforts'.

Third, this secondary layer of manipulation covers the splitting of rows between parts to various degrees up to the point of condensing row transformations into unordered collections. The penultimate line of the poem, 'Que comprendre à ma parole? Il fait qu'elle fuie et vole!' is a case in point. The ensemble's music is assembled from four different $P$ and $I$ row transpositions, which each account for the pc content of between one and three bars of this 


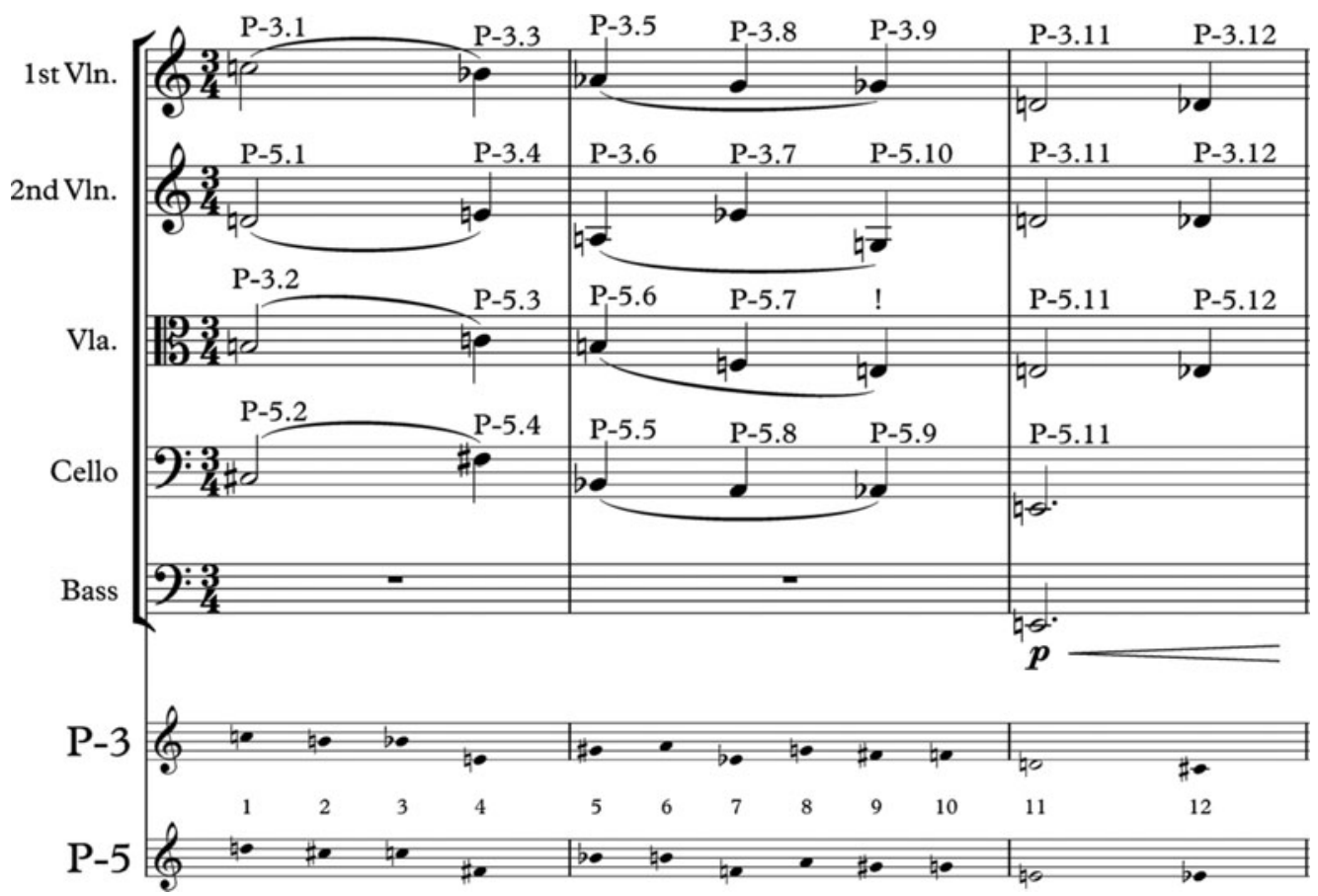

Example 3 O saisons, ô châteaux!, bb. 51-3, P-3 and P-5. @ 1960 (renewed) EMI Mills Music, Inc. Exclusive print rights administered by Alfred Music. All rights reserved.

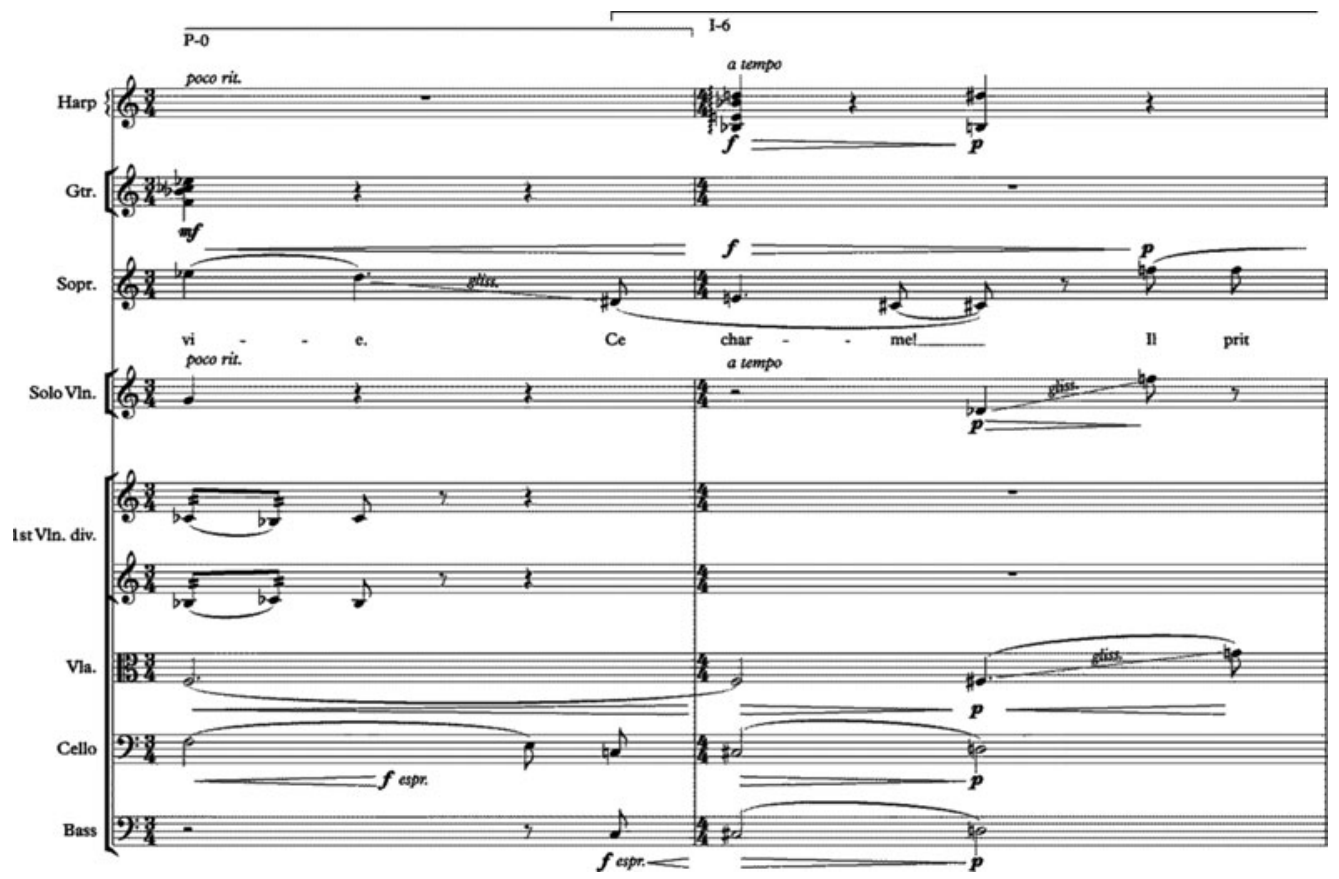

Example 4 O saisons, ô châteaux!, bb. 94-5, with overlapping row transformations. ๑ 1960 (renewed) EMI Mills Music, Inc. Exclusive print rights administered by Alfred Music. All rights reserved. 


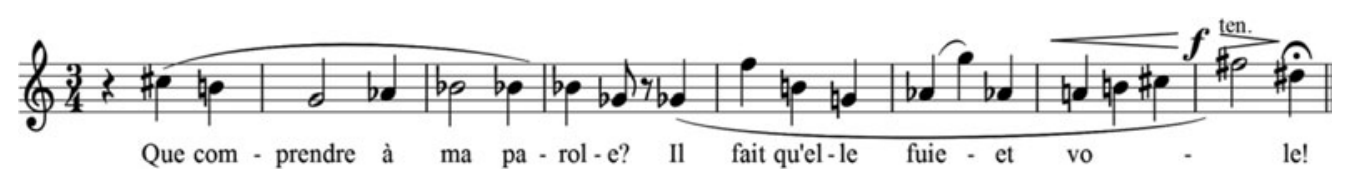

Example 5 O saisons, ô châteaux!, bb. 101-8, soprano. ๑ 1960 (renewed) EMI Mills Music, Inc. Exclusive print rights administered by Alfred Music. All rights reserved.

eight-bar episode but do not overlap (Example 5, bb. 101-8). The soprano part pc content is accounted for in each transposition; but since the four row transformations are condensed into unordered collections, the melody is no neat row occurrence but a pick-and-mix of pcs from these collections. Again, Lutyens plays with her set text, which here emphasizes the magician's unintelligible speech. While the structure of this speech (or of the row pcs) may be obscure, the initiated one knows that a powerful force (the row and its transformations) is at work beneath the seemingly random pcs on the surface.

Overlapping, dovetailing, and split rows provide Lutyens with a close connection with her set text, but they also account for a degree of her particular non-Webernian timbre. The vocal line features intervals which do not occur in the row or its transformations, such as major seconds and fourths (cf. Example 5). Missing pcs are provided in the ensemble. The dovetailing of rows offers a way to allow rows to flow into each other without edgy section borders or awkward rests. The third, most striking, and important feature of $O$ saisons, however, is its repetitions. In the later stages of her career, Lutyens was a confident user of pedal points, cell or collection repetition, and even whole repeated phrases. On one end of the spectrum in this respect stands the Concertante for Five Players op. 22 (Lutyens's tribute to the Pierrot ensemble combination). Here, the violin provides a sort of pitched crotchet metronome throughout the entire fifth movement, 'Recitativo - Lento'. This metronome is emphasized through the curiously hollow sound of its interval between the open D string and the D flageolet two octaves above it. On the other end sits the lyric drama Isis and Osiris. In Isis's lament on the death of Osiris, time seems to stop as Isis rises, 'prostates [sic] herself, and slowly raises her head' for her unaccompanied soliloquy of about five minute's duration, arguably the opera's centre piece (and its only 'survivor', which was published as a stand-alone piece and has been recorded ${ }^{67}$ ). The lament announces the opera's turn from the previous rituals of birth and the giving of time towards rituals of death and the loss of time (or a sense of it). By arresting the flow of the tone row in repetitive melodic phrases, Lutyens prepares this turn of focus. Thus in the later part, two multi-bar phrases are each repeated four times; the first mirrors the text's lamenting recital of the loss of different attributes of Osiris: 'Mourn, o mourn, the loss of my sweet Nile; Mourn, o mourn, the death of Northern winds; mourn, o mourn, the lengthening of the night' (Example 6). The second is an enumeration of all the things that will die or disappear as a consequence of the loss of Osiris: 'The grass no longer green; The withering of all the trees; The flowers that flower no more; The shrubs that shed their leaves', followed by the fourth and final repetition of the previous phrase: 'then mourn,

67 Elisabeth Lutyens (1906-1983). Jane Manning (sopr.), Jane’s Minstrels. NMC Recordings, 1992/2012. 

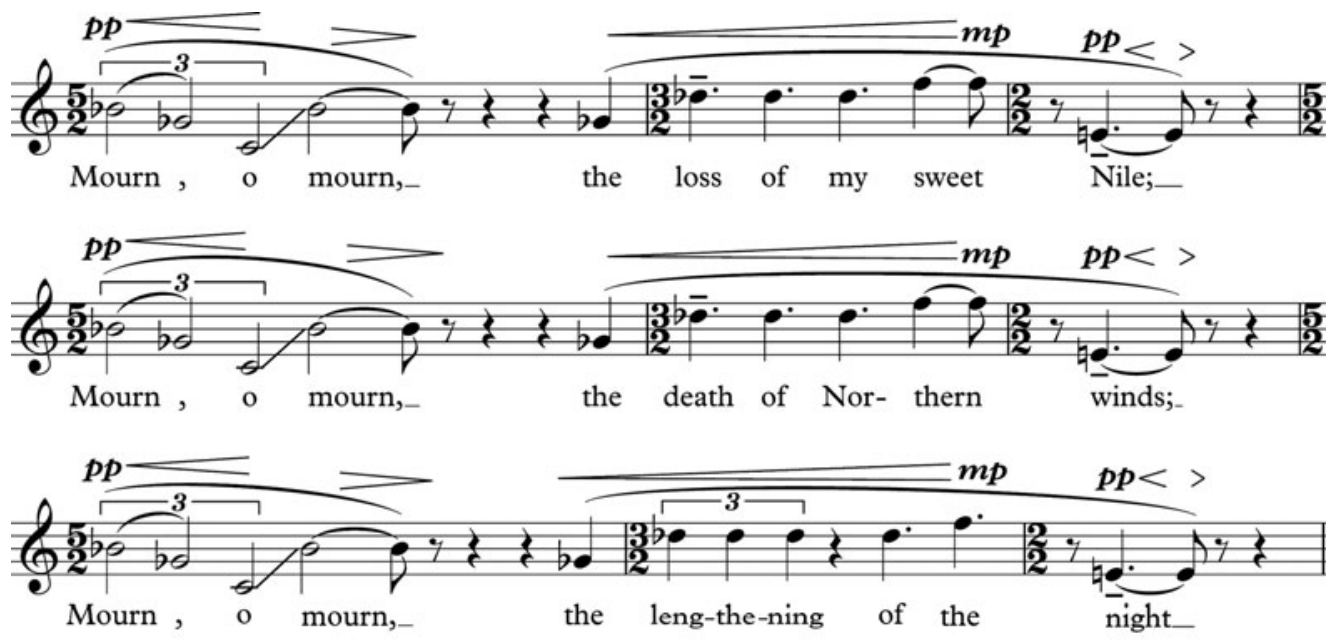

Example 6 Isis and Osiris, Lament of Isis, p. 88, bb. 6-14. Reproduced by kind permission of University of York Music Press.
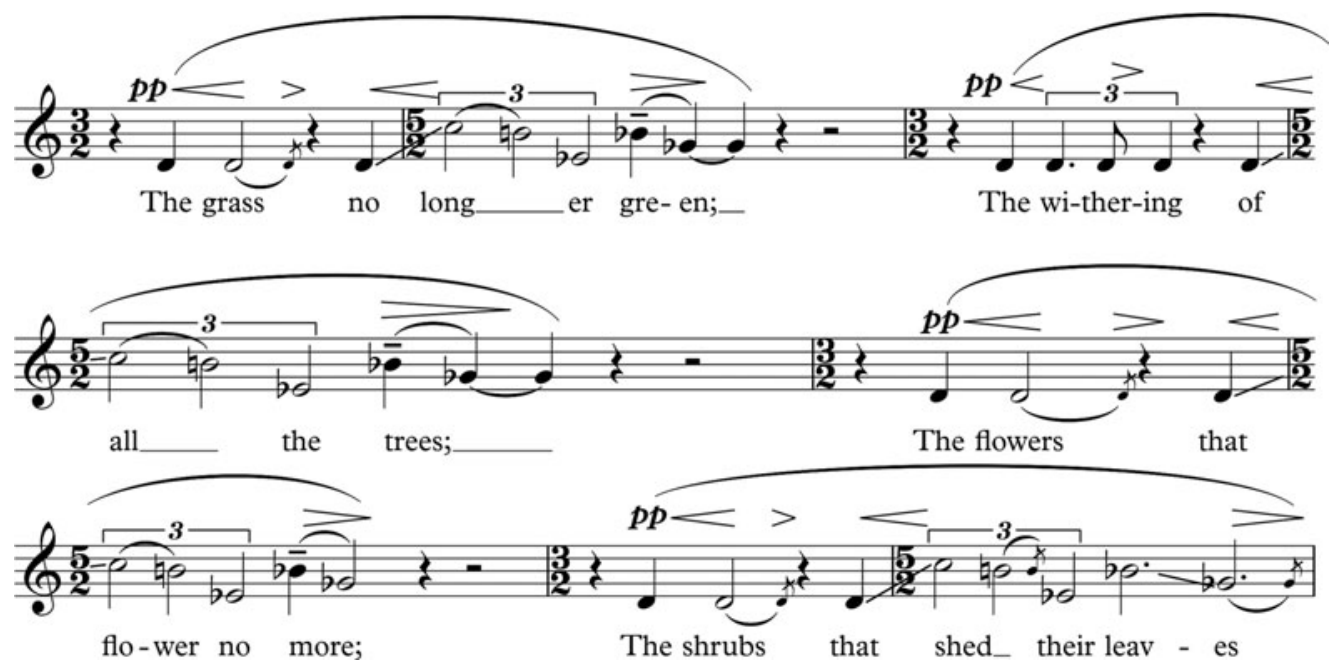

Example 7 Isis and Osiris, Lament of Isis, p. 88, bb. 21-8. Reproduced by kind permission of University of York Music Press.

o mourn, the dying of the Nile' (Example 7). Even within this phrase, Lutyens repeats the first two pitches of the three-tone cell $\mathrm{B} b-\mathrm{G} b-\mathrm{C}$.

On a more basic level, the striking similarity between the beginning of Isis's lament in the opera and the soprano's first line in O saisons, ô châteaux! (Example 8, cf. Example 1b) show that Lutyens returned to chromaticism and repetition as markers of (magical) ritual in a later lament for high voice.

O saisons features no large-scale phrase repetitions like Isis and Osiris or metronomic pedal points like the Concertante, but prototypes of these very characteristic devices appear in the Cantata. The later opera's sense of arrested time, for example, is achieved by dramatic 


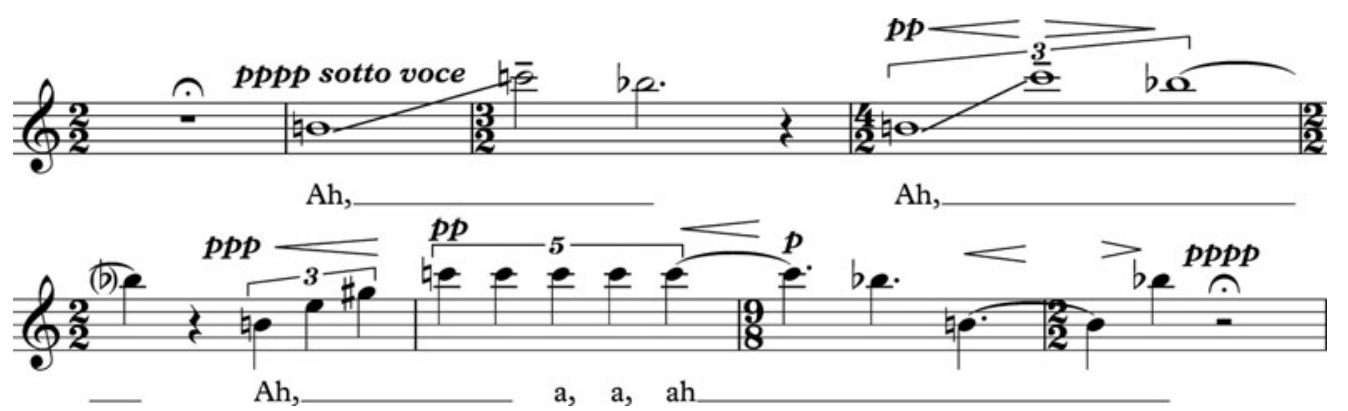

Example 8 Isis and Osiris, beginning of the Lament of Isis, p. 87, rehearsal number 134. Reproduced by kind permission of University of York Music Press.

repetition effects such as the harmonically completely static transition from section A into B (bb. 38-41), which spreads order nos. 1-6 of an inversion transposition vertically through the ensemble and repeats them insistently through a crescendo into their climactic resolution in b. 42 's soprano outburst. ${ }^{68}$

Two moments of larger-scale repetition stand out in $O$ saisons; the first and most memorable in bb. 60-3, where a broken chord in the solo violin is pinned against a different pedal point in the ensemble, and the second in bb. 73-5, where string parts repeat various two-note cells. The former figure constitutes one the most dramatic moments in the Cantata, but it is harmonically ambiguous (Example 9). The solo violin's motif could be described as a B minor chord in first inversion, or else as the pc collection [037], or as order nos. 6, 10, and 11 of the row's prime form. The remaining instruments (mandolin, harp, and strings) hold a pedal composed of a chromatic tetrachord, or the symmetric pc collection [0167], or order nos. $1,8,9$, and 12 .

In either scenario Lutyens would join the serial mainstream of taking dodecaphony beyond note counting and towards expressivity. Yet to ask whether this ambiguity also constitutes a clash between tonal and atonal elements or of a hierarchical and a symmetric pc collection or rather a tonal-serial hybrid may yet again be the wrong question, as it would seek to locate Lutyens in a struggle between (male) insiders and (female) outsiders of some kind of superior serial technique. Lutyens is neither a member of a Viennese mainstream serialism whose rules she would be interested in breaking, nor does she need to be portrayed as the outsider woman composer with an incomplete grasp of the technique and the resulting need to tame it. This short section shows Lutyens searching for less rigid forms of expression through twelve-tone music, a search which yet again leads her back to the magical properties and allusions of her set text: the collection of order nos. in these four questionable bars misses its no. 7; the music's spell is yet again an ambiguous one. One of the most perplexing moments of the piece thus lines up with Lutyens's careful path past the pitfalls of masculine vs feminine interpretations of serialism.

68 The opposite effect occurs in bb. 87-90, where similarly stacked-up pedal points in the ensemble disappear gradually in a diminuendo al niente. 


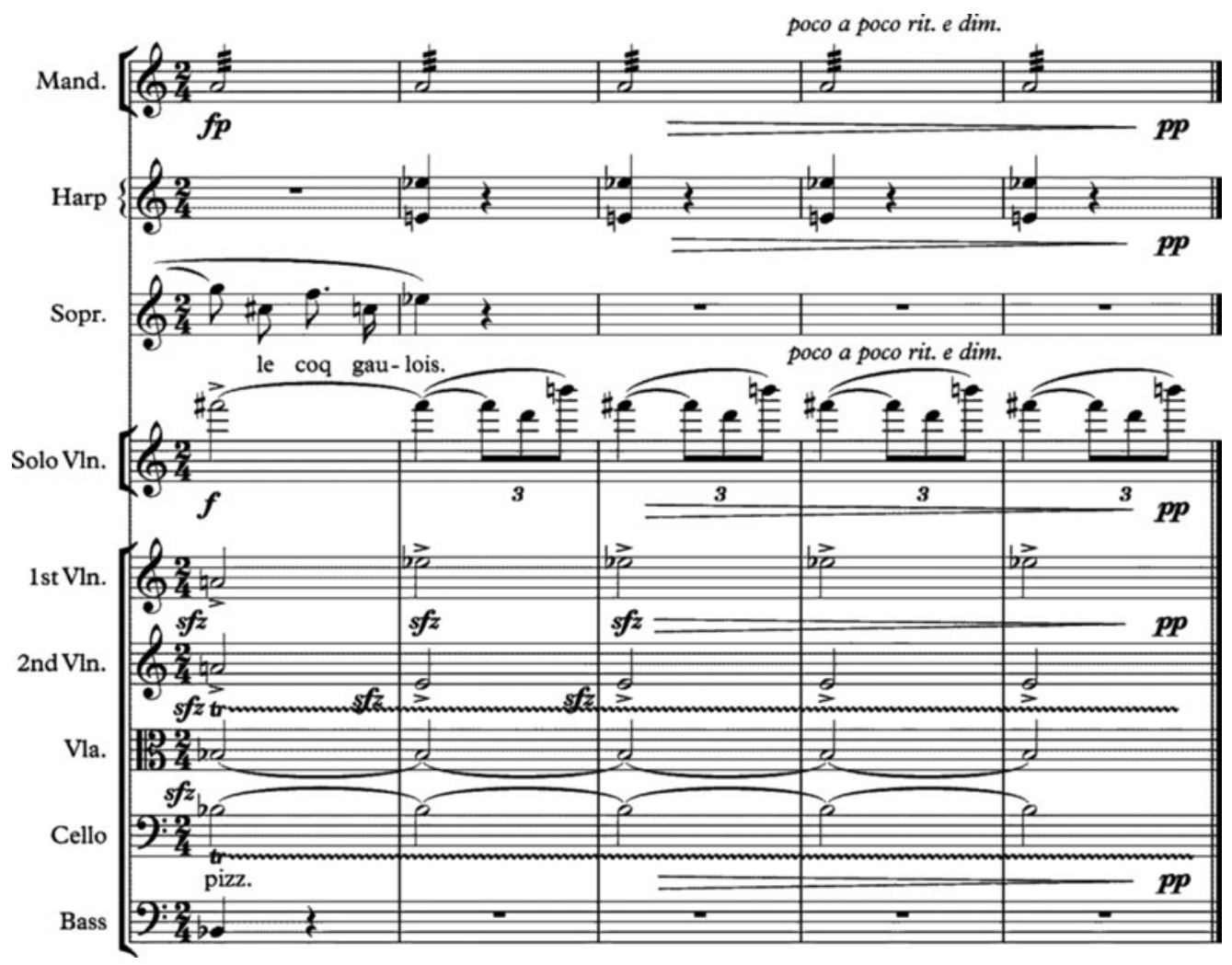

Example 9 O saisons, ô châteaux!, bb. 59-63. @ 1960 (renewed) EMI Mills Music, Inc. Exclusive print rights administered by ALFRED MUSIC. All rights reserved.

Where questions of the hybridity of tonality and serialism are concerned, this and other occurrences have proved problematic for O saisons. Lutyens's feminist analyst Sally MacArthur locates one of the composer's issues in what she provokingly calls 'liberal sprinklings of tonal language. ${ }^{69}$ They occur throughout the piece and are vaguely reminiscent of an AustroGerman fin-de-siècle tradition of composers such as Franz Schreker, Alexander Zemlinsky, or Mahler. These moments hinge on brief tonal reminiscences of, for example, $C \sharp$ major (b. 12), F minor/major (b. 16), B major (b. 28), and Eb minor (b. 38) triads, sometimes featuring a falling minor second appoggiatura, Lutyens's marker of lament. While it is tempting to read them as 'lapses' in the row's consistency, they do not actually violate whichever row transformation dominates the surrounding pitch organization. Rather, they assist Lutyens's twelve-tone alchemy, which seeks to create the lump of gold (a lush sounding piece of music) from base materials (12 pcs structured in collections or rows), just as the above ambiguity between $\mathrm{B}$ minor and a tetrachord skirts decisions for or against strict serialism or tonality. 
In defence of her claim that a twelve-tone piece needs to sound good, above all, Lutyens herself maintained that 'the proof of the pudding is still in the eating. ${ }^{70}$ This 'pudding' is the lamenting and magical sound Lutyens identified early on in the composition process as the piece's defining feature. Yet, 'tonal sprinkles', switches from ordered to unordered collections, repetitions, and such like can still pose a threat to its composer's integrity, if this composer is the wife of a Schoenberg pupil (Edward Clark) and claims to have invented it all on her own. As a consequence, feminist authors such as MacArthur have sought to defend Lutyens against potential attacks that might denigrate a serialism that does not adhere to an imaginary textbook.

\section{Femininity, serialism, and alchemy}

Lutyens was of course no less capable of following serialism's rules than any other composer sitting down to write a piece of serial music. The difference between her and an established set of serial composers such as Schoenberg, Berg, and Webern is therefore not that she actually uses the technique differently, but that her decisions concerning the technique are frequently read in a different light (with the additionally complicating factor that she was British). Thus, in an exemplary move to defend Lutyens's idiosyncratic use of her material, MacArthur harks back to Susan McClary's well-known judgements about Schoenberg, which in their turn were foreshadowed in Bryan Simms's analytical language in The Atonal Music of Arnold Schoenberg, 1908-1923:

[Lutyens's] mastery of style is, without question, exemplary. Yet, the aesthetic underpinning serialism could be viewed as the most alienating territory of all for a woman to enter. It is arguably the most rule-ridden, rational style of music to have emerged, despite, perhaps, sounding highly dissonant, chaotic, and disorganised. In her critique of Schoenberg, Susan McClary argues that Schoenberg's invention of serialism, an invention of the highest intellectual achievement, allowed him to continue creating what she describes as his 'madwoman's discourse' of the earlier, atonal, expressionist works, such as Erwartung (Expectation), while at the same time ridding the music of its feminine associations. ${ }^{71}$

MacArthur argues that Lutyens's strategy in the light of this issue was to 'feminize' her music:

Far from sounding irrational and chaotic, then, as McClary implies is the case with Schoenberg's music, this work [ $O$ saisons, ô châteaux!] sounds coherent as if it has been logically organized. [ ... ] It could even be the case that at a subconscious level Lutyens has made a deliberate choice to feminize her music, while Schoenberg's main project was to defeminize his music by shifting focus away from the sound of the music to the written particularities of the score. ${ }^{72}$

70 Elisabeth Lutyens, 'A Working Lifetime', 57.

71 MacArthur, Feminist Aesthetics, 97-8.

72 MacArthur, Feminist Aesthetics, 99. 
What is more, according to MacArthur, Lutyens sets out to 'soften' the Cantata's surface by making it sound tonal, thereby 'taming' serialism. ${ }^{73}$ The composer would probably have strongly refuted this reading, as can be gleaned from utterances in her autobiography and elsewhere. She was very much a child of the generation of composers who, like Maconchy, felt that the label 'woman composer' was at best offensive, at worst a career breaker. ${ }^{74}$ Nevertheless, O saisons, ô châteaux! seems to confirm MacArthur's concept of a feminized serialism to a large degree: it has a lush, impressionist string texture and, like much British concert music of the early twentieth century, is rich in tunes, and features longer duration values or pedal points. However, any feminine softness is balanced, if not overturned, by fluctuating dynamic waves enabled by these same pedal points and long durations. The dynamic centre is in fact piano, with wide variations in both directions. The piece starts and ends in pianissimo, and at times soars to a triple forte (b. 26, strings; repeated $s f z$ in b. 59, upper strings) or retreats to a triple piano (b. 90, guitar, strings al niente; b. 101, strings). The least common dynamic indication is the exact middle between these extremes - mezzoforte. Instead, sharp crescendi and decrescendi dominate the scene already in the first seven bars, which see a compressed surge from pianissimo to fortissimo (paralleled in density of texture), which then recedes.

Needless to say, such devices as tonal allusions, string instruments, and melody in a serial piece are not the woman composer's prerogative. Gendered pigeonholing of Lutyens's music in the literature obscures the fact that she was working on a solution for a dilemma that haunted twelve-tone music - on the one hand the limitation of expression in Schoenberg's early, strict serialism, on the other the danger of serialism 'falling back' into tonality where it sought to address this limitation. In contemporary accounts, the intrusion of tonality into serialism for the purpose of widened expressive range was discussed. A few examples may suffice: in 1940, Ernst Krenek had published his manual of serialism, whose first lesson taught the student to avoid rows with too many tonal intervals (major and minor triads). ${ }^{75}$ In 1947, Schoenberg replied defensively to a letter from Leibowitz, who had alerted Schoenberg to the tonal sounds in several of his works:

It was not my purpose to write dissonant music, but to include dissonance in a logical manner without reference to the treatment of the classics: because such a treatment is impossible. [... ] It is true that the Ode [to Napoleon Bonaparte] at the end sounds like E flat. I don't know why I did it. Maybe I was wrong, but at present you cannot make me feel this. ${ }^{76}$

Virgil Thomson, finally, reflected in The Score in 1952 that 'nontonal music, any music of which the key and mode are consistently obscure, has so far always turned out to be

73 MacArthur, Feminist Aesthetics, 99-100.

74 Despite Lutyens's keen awareness of the problems she faced because of her gender, she chose to pit herself against the BBC's conservative stance towards the New Music, rather than against gender stereotypes.

75 Ernst Krenek, Studies in Counterpoint. Based on the Twelve-Tone Technique (New York: G. Schirmer, 1940), 1.

76 Erwin Stein, ed., Arnold Schoenberg. Letters (London: Faber \& Faber, 1964), 248. 
contrapuntal. It cannot be harmonic in the conventional sense, because chords pull everything back into a tonal syntax. ${ }^{77}$

Even in later twentieth-century assessments of serialism, this topic was still discussed, for example in David Matthews's claim with regard to serial expressivity:

Despite Schoenberg's assertion to the contrary, the musical language which he formulated and from which most currently fashionable styles are descended, is limited in expressive range. [ . . . ] Of those composers who have used a Schoenbergian language, the most successful have been those who have expressionist things to say: Peter Maxwell Davies, for example. In short, serialism [...] cannot easily evoke states of joy, gaiety, exuberance. If composers still want to express such emotions in their music, they might profitably consider how [Michael] Tippett's language in its development from orthodox tonality to pantonality has always been a potent vehicle for the widest range of expression. ${ }^{78}$

A hint of this discourse still permeates Taruskin's discussion of Berg's aesthetic balancing act between limiting technique and forbidden 'tonal pleasures': ${ }^{79}$ Berg's 'art remained one of affective association, his expressive aims remained traditionally humanistic, concerned with the representation, and possible transmission, of subjective feelings like erotic love (in the Lyric Suite), or grief and consolation (in the Concerto). It was to these ends that Berg sublimated the intellectual curiosity that attracted him to technical tours de force. ${ }^{80}$ Lutyens's serialism boldly takes this step into the unknown, enchanting serialism with old wisdom (tonality) and so infusing it with expressivity.

Lutyens has been sidelined by this tradition of making serialism expressive through intrusions of tonality because her innovations have so far been read as feminization - a label that has rarely helped any artist or composer in the patriarchal structures of the Western world. The new magical serialism in O saisons, ô châteaux! stems from an individual and specific expressive aesthetic flowing into it from its set text, but it does not provide an allencompassing principle for twelve-tone music. Yet the Cantata may serve as a reminder that the solutions of the Schoenberg school cannot claim that privilege either. Rather, Lutyens's unique perspective on the technique and her early rethinking of dodecaphony's potential locate the piece firmly within the canons of an innovating modernism. Lutyens's interest in magic, a pre-modern, anti-mechanical, and elitist practice connects her to fellow modernists Yeats, Bernard van Dieren, and Constant Lambert on the one hand, and to the numerological Schoenberg on the other. If the serial strategies in $O$ saisons, ô châteaux! are understood as 'personal style' as in MacArthur's argument, ${ }^{81}$ then the fact will be overlooked that women composers work no less creatively around technical restrictions than their male counterparts.

77 Virgil Thomson, 'Reflections', The Score 6 (May 1952), 11-14.

78 David Matthews in 1980, quoted in Arnold Whittall, 'The Matthews Mark: A Philosopher's Perspective', Tempo 65/257 (2011), 3.

79 Alex Ross characterises Berg's tonal moments as 'forbidden pleasures': The Rest Is Noise, 226.

80 Taruskin, The Oxford History of Western Music, 719.

81 MacArthur, Feminist Aesthetics, 99. 
But more importantly, MacArthur blows into the same horn as the masculinist tradition she criticizes with this argument of feminization: if serialism needs to be tamed or 'tonalized' for a woman to find it a useful way of organizing her pitch, then the technique is indeed essentially masculine and only a tonal serialism can be heard as non-masculinist and dealt with by women.

For a combative and defensive Elisabeth Lutyens, composing was always going to be a balancing act between charges of imitation and inability, an act which she mastered with characteristic verve. Yet, the gendered perception of her earlier experiments with serialism has obscured the relevance of (at least some of) her works for pre-1950s British modernism. Lutyens seemed caught between the rejection of traditional analysis of feminist New Musicology scholars (in Lutyens's case MacArthur) and a still male-dominated canon and understanding of serial music. A compromise is a contextual analysis which, for instance, reads $O$ saisons $\hat{o}$ châteaux! in the tradition of an enchanted modernism, but highlights its points of departure from the means used by similarly minded composers to this end: $O$ saisons does not go near standard serial traits such as a Grundgestalt designed according to numerical considerations, or transformations drawn from a row matrix or permutations. The Cantata's understanding of serialism is more melodic, designed to fit its set text. If more than thirty years of musicological discourse about gender, canon, and analysis have been good for anything, it must be that such a compositional strategy is not considered automatically feminine anymore and thus, by default, 'dry', 'hamstrung', or otherwise inferior. The situation of ongoing canon-building in the complex field of British musical modernism can only profit from a commitment to this insight and the firm embracement of its women composers.

\section{Bibliography}

Adorno, Theodor W. 'The Aging of the New Music', in Essays on Music: Selected, with Introduction, Commentary, and Notes by Richard Leppert; New Translations by Susan Gillespie. Berkeley and London: University of California Press, 2002. 181-202.

Battersby, Christine. Gender and Genius: Towards a Feminist Aesthetics. London: Women's Press, 1989.

Blake, Andrew. The Land without Music: Music, Culture, and Society in Twentieth-Century Britain. Manchester: Manchester University Press, 1997.

Bradshaw, Susan and Richard Rodney Bennett. 'Elisabeth Lutyens. Letter to the Editor', The Listener, 29 December 1966. 969.

Citron, Marcia. 'Women and the Lied, 1775-1850', in Women Making Music, ed. Jane Bowers and Judith Tick. Champaign, IL: University of Illinois Press, 1986. 224-48.

—. 'Women and the Western Art Canon: Where Are We Now?', MLA Notes 64/2 (2007), 209-15.

Elias, Brian. 'Introduction to O saisons, ô châteaux!', in Elisabeth Lutyens, Letters to Brian Elias, with related material, 1965-83. GB-Lbl Add. MS. 71114: 1965-83.

Fowlie, Wallace. Rimbaud: The Myth of Childhood. London: Dennis Dobson, 1946.

Hanegraaff, Wouter. 'The Unspeakable and the Law. Esotericism in Anton Webern and the Second Viennese School', in Music and Esotericism, ed. Laurence Wuidar. Leiden and Boston: Brill, 2010. 329-53.

Hayes, Malcolm. 'Music', The Listener, 5 January 1984, 27-8.

Hisama, Ellie M. Gendering Musical Modernism: The Music of Ruth Crawford, Marion Bauer, and Miriam Gideon. Cambridge: Cambridge University Press, 2001.

Krenek, Ernst. Studies in Counterpoint. Based on the Twelve-Tone Technique. New York: G. Schirmer, 1940.

Larner, Gerald. 'Frozen Music: Elisabeth Lutyens at Sixty', The Listener, 24 November 1966, 784.

Leibowitz, René. Qu'est-ce que la musique de douze sons? Le Concerto Pour Neuf Instruments op. 24 d'Anton Webern. Liège: Editions Dynamo, 1948. 
Introduction à la musique de douze sons. Les Variations Pour Orchestre op. 31 d'Arnold Schoenberg. Paris: L'Arche, 1949.

Lutyens, Elisabeth. Cantata for Soprano and Strings Opus 13: O Saisons, O Châteaux! MS, November 1946, GB-Lbl Add MS 64639.

. 'A Working Lifetime', The Listener, 8 July 1971, 57.

-. A Goldfish Bowl. London: Cassell, 1972.

Lutyens, Elisabeth and Bernard Palmer, 'Interview', 1969. www.bbc.co.uk/programmes/p02kycf4 (accessed 24 April 2017).

Lutyens, Elisabeth and Robert Saxton. 'Elisabeth Lutyens at 75. An Interview with Robert Saxton', The Musical Times 122/1660 (1981), 368-9.

Lutyens, Elisabeth and Murray Schafer. 'Elizabeth Lutyens', in British Composers in Interview, ed. Murray Schafer. London: Faber \& Faber, 1963. 103-12.

MacArthur, Sally. Feminist Aesthetics in Music. Westport, CT, and London: Greenwood Press, 2002.

- 'The Woman Composer, New Music and Neoliberalism', Musicology Australia 36/1 (2014), 36-52.

Maconchy, Elizabeth et al., 'A Short Symposium of Women Composers', Composer 6 (1961), 19-22.

Mason, Colin. 'Review: Voice and Orchestra', Music \& Letters 43/1 (1962), 90-1.

Mathias, Rhiannon. Lutyens, Maconchy, Williams and Twentieth-Century Music: A Blest Trio of Sirens. Farnham: Ashgate, 2012.

McClary, Susan. Feminine Endings: Music, Gender, and Sexuality. Minneapolis, MN: University of Minnesota Press, 1991.

Milner, Anthony. 'English Contemporary Music', in European Music in the Twentieth Century, ed. Howard Hartog. London: Penguin, 1957, 1961. 132-51.

Murat, Michel. L'art de Rimbaud. Paris: José Corti, 2002.

Olive, Vivienne. 'Elisabeth Lutyens fällt vollkommen aus dem Rahmen', in Annäherung: An sieben Komponistinnen, IV, ed. Renate Matthei and Brunhilde Sonntag. Kassel: Furore, 1988, 36-45.

Parker, Rozsika and Griselda Pollock. Old Mistresses. Women, Art and Ideology. London: Pandora, 1981.

Parsons, Laurel. 'Early Music and the Ambivalent Origins of Elisabeth Lutyens's Modernism', in British Music and Modernism. 1895-1960, ed. Matthew Riley. Farnham: Ashgate, 2010, 269-91.

Payne, Anthony. 'Lutyens's Solution to Serial Problems', The Listener, 5 December 1963, 961.

-. 'Lutyens, (Agnes) Elisabeth', in The New Grove Dictionary of Music and Musicians, vol. 15, 2nd edn, ed. Stanley Sadie and John Tyrrell. London: Macmillan, 2001. 389-92.

Rimbaud, Arthur. Selected Verse Poems of Arthur Rimbaud, trans. Norman Cameron. London: Hogarth Press, 1942.

- Les plus belles ouvres. Collection de textes français publiée sous la direction d'André Labarthe. London: Barnard \& Westwood, 1943.

. Rimbaud Complete. Volume 1: Poetry and Prose, trans. Wyatt Mason. New York: Modern Library, 2003.

Ross, Alex. The Rest is Noise. New York: Picador, 2007.

Saxton, Robert. 'Elisabeth Lutyens', New Music 88 (1988), 9-16.

Schaarwächter, Jürgen. "Chasing a Myth and a Legend. The "British Musical Renaissance" in a "Land without Music”, The Musical Times 1904 (2008), 53-60.

Schmitz, Oscar A. H. Das Land ohne Musik. Englische Gesellschaftsprobleme, 3rd edn. Munich: G. Müller, 1914.

Schoenberg, Arnold. 'The Blessing of the Dressing' (1948), in idem, Style and Idea (60th anniversary edition), ed. Leonard Stein. Berkeley: University of California Press, 1975, 382-6.

Schuller, Gunther. Review of 'Konzert, Op. 24. Für Flöte, Oboe, Klarinette in B, Horn in F, Trompete in C, Posaune, Geige, Bratsche, \& Klavier by Anton von Webern', Notes, Second Series, 17/1 (1959), 136-7.

Solie, Ruth. 'No "Land without Music" After All', Victorian Literature and Culture 32/1 (2004), 261-76.

Starkie, Enid. Arthur Rimbaud. London: Faber \& Faber, 1938, 1947, 1961.

- Arthur Rimbaud, 2nd edn. London: Hamish Hamilton, 1947.

Stein, Erwin, ed. Arnold Schoenberg. Letters. London: Faber \& Faber, 1964.

Taruskin, Richard. The Oxford History of Western Music. Vol 4: Music in the Early Twentieth Century. Oxford: Oxford University Press, 2010.

Tenant-Flowers, Sarah Jane. 'A Study of Style and Technique in the Music of Elisabeth Lutyens'. PhD diss., University of Durham, 1991.

Thomson, Virgil. 'Reflections', The Score 6 (May 1952), 11-14.

Timms, Colin, et al. 'Cantata', in The New Grove Dictionary of Music and Musicians, 2nd edn, ed. Stanley Sadie and John Tyrrell. London: Macmillan, 2001.

Unsigned. 'Gerald Cooper Concert', The Times, 12 February 1947, 6.

Unsigned. 'Our London Letter: Gerald Cooper Concert', The Western Morning News, 13 February 1947, 2.

Walsh, Stephen. 'Music Last Week', The Listener, 8 December 1966, 869. 
'Music Last Week', The Listener, 29 December 1966, 977.

'Elisabeth Lutyens's “Time Off?”', The Listener, 2 March 1972, 284.

Weissmann, John S. 'The Music of Elisabeth Lutyens', The Listener, 3 August 1950, 177.

Whittall, Arnold. 'The Matthews Mark: A Philosopher's Perspective', Tempo 65/257 (2011), 2-10.

Yeats, W. B. 'Ideas of Good and Evil', in Essays and Introductions. New York: Macmillan Company, 1961.

\section{Discography}

'Lament of Isis on the Death of Osiris'. On Elisabeth Lutyens (1906-1983). Jane Manning (sopr.), Jane's Minstrels. NMC Recordings, 1992/2012.

O saisons, ô châteaux! On Red Leaves. Teresa Cahill (sopr.), Brunel Ensemble, Christopher Austin (cond.). Signum Recordings, 1996. 